\title{
REVIEW
}

\section{Gene expression analysis in RA: towards personalized medicine}

\author{
AN Burska ${ }^{1}, \mathrm{~K} \mathrm{Roget}^{2,10}$, M Blits ${ }^{3}, \mathrm{~L}$ Soto Gomez ${ }^{4}, \mathrm{~F}$ van de Loo ${ }^{5}, \mathrm{LD} \mathrm{Hazelwood}^{6}, \mathrm{CL} \mathrm{Verweij}^{3}, \mathrm{~A} \mathrm{Rowe}^{7}, \mathrm{GN} \mathrm{Goulielmos}^{8}$, \\ LGM van Baarsen ${ }^{9}$ and $F$ Ponchel ${ }^{1}$
}

Gene expression has recently been at the forefront of advance in personalized medicine, notably in the field of cancer and transplantation, providing a rational for a similar approach in rheumatoid arthritis (RA). RA is a prototypic inflammatory autoimmune disease with a poorly understood etiopathogenesis. Inflammation is the main feature of RA; however, many biological processes are involved at different stages of the disease. Gene expression signatures offer management tools to meet the current needs for personalization of RA patient's care. This review analyses currently available information with respect to RA diagnostic, prognostic and prediction of response to therapy with a view to highlight the abundance of data, whose comparison is often inconclusive due to the mixed use of material source, experimental methodologies and analysis tools, reinforcing the need for harmonization if gene expression signatures are to become a useful clinical tool in personalized medicine for RA patients.

The Pharmacogenomics Journal (2014) 14, 93-106; doi:10.1038/tpj.2013.48; published online 4 March 2014

Keywords: arthritis; gene expression; pharmacological biomarker; rheumatoid

\section{INTRODUCTION}

Gene expression profiling is the analysis of the activity (the expression) of thousands of genes, in isolation or all at once, to create a global picture of biological functions. Many technical platforms allow the measure of the entire genome activity simultaneously in a particular cell or tissue or even organ. Gene expression profiling has recently been at the forefront of advance in personalized medicine, notably in the field of cancer and transplantation. The value of gene expression signatures was demonstrated for the prediction of tumour behaviour in several types of cancer, distinguishing groups of patients with specific tumour grades and/or prognosis, ${ }^{1-5}$ notably compared with the sole use of clinical variables in lung adenocarcinoma, 6,7 acute lymphoblastic leukaemia, ${ }^{8}$ B-cell lymphoma, ${ }^{9-11}$ prostate cancer, ${ }^{12}$ breast, ${ }^{13,14}$ endometrial, ${ }^{15}$ colorectal, $^{16}$ hepatocellular carcinoma $^{17,18}$ and other gastrointestinal cancers. ${ }^{19}$ Estrogen receptor status in breast tumour was reflected by specific gene expression patterns dividing high- and low-grade tumours and associated with specific biological, histological or stage features as well as metastatic propensity. ${ }^{20-22}$ Similar advances were also seen in organ transplantation with respect to rejection. Peripheral blood gene profiling was shown to provide adequate monitoring of immuno-suppression in individual patients who received a liver transplant ${ }^{23}$ as well as actually provide an alternative monitoring technology to cardiac biopsy after allograph heart transplant with significantly lower discomfort for patients. ${ }^{24}$ The AlloMap test for allograph heart transplant rejection has been Food and Drug Administration (FDA) approved (in 2008) in the USA, and three main clinical trials provided evidence of the usefulness of this gene expression signature. ${ }^{25-27}$ However, as for any other biomarkers, adoption in clinical practice is slow, and evidence that they have/will change practice are still lacking. Altogether, these results demonstrated the utility of gene expression as a modern tool able to provide personalized-specific information.

Inflammation is a biological process associated with the production of many factors, therefore suggesting that changes in gene expression could provide signatures at different phases or stages of inflammatory diseases such as rheumatoid arthritis (RA). This review will analyze currently available information with respect to RA diagnostic, prognostic and prediction of response to therapy with a view to highlight the current abundance of data, whose comparison is often inconclusive due to mixed use of a different material source, experimental methodology and statistical tools, reinforcing the need for harmonization if gene expression signature are to become a useful clinical tool in personalized medicine for RA patient's benefit.

Gene expression as a tool to investigate pathogenesis in RA $\mathrm{RA}$ remains a prototypic inflammatory autoimmune disease with a poorly understood etiopathogenesis despite recent advances in unraveling the genetic contribution to RA revealing over 50-60 risk loci. ${ }^{28-31}$ RA is very heterogeneous as highlighted by a stronger genetic contribution to anti-citrullinated protein antibodies (ACPA)-positive disease compared with ACPA-negative disease, potentially resulting in two divergent pathogenic models $^{32-34}$ with different rates of progression ${ }^{35-37}$ and response to treatment. ${ }^{36,38}$

Besides these genetic advances in the understanding of RA, gene expression profiling can provide useful information to this understanding as well. Genome-wide gene expression analysis

${ }^{1}$ Leeds Institute of Rheumatic and Musculoskeletal Medicine and Leeds Musculoskeletal Biomediacal Research Unit, The University of Leeds, Leeds, UK; ${ }^{2}$ TcLand Expression, Huningue, France; ${ }^{3}$ Department of Pathology and Rheumatology, Inflammatory Disease Profiling Unit, VU University Medical Center, Amsterdam, The Netherlands; ${ }^{4}$ School of law, The University of Leeds, Leeds, UK; ${ }^{5}$ Department of Rheumatology Research and Advanced Therapeutics, Nijmegen Centre for Molecular Life Sciences, Nijmegen, The Netherlands; ${ }^{6}$ School of Molecular and Cellular Biology, Faculty of Biological Sciences, University of Leeds, Leeds, UK; ${ }^{7}$ Janssen Research and Development, High Wycombe, UK; ${ }^{8}$ Molecular Medicine and Human Genetics Section, Department of Medicine, University of Crete, Heraklion, Greece and ${ }^{9}$ Clinical Immunology and Rheumatology, Academic Medical Center, University of Amsterdam, Amsterdam, The Netherlands. Correspondence: Dr F Ponchel, Leeds Institute of Rheumatic and Musculoskeletal Medicine, The University of Leeds, Clinical Sciences Building, St James's University Hospital, Leeds LS9 7TF, UK.

E-mail: F.Ponchel@leeds.ac.uk

${ }^{10}$ Current address: BioSIMS Technologies, Rouen, France.

Received 16 August 2013; revised 29 October 2013; accepted 26 November 2013; published online 4 March 2014 
Table 1. Gene expression studies investigating the pathogenesis of RA

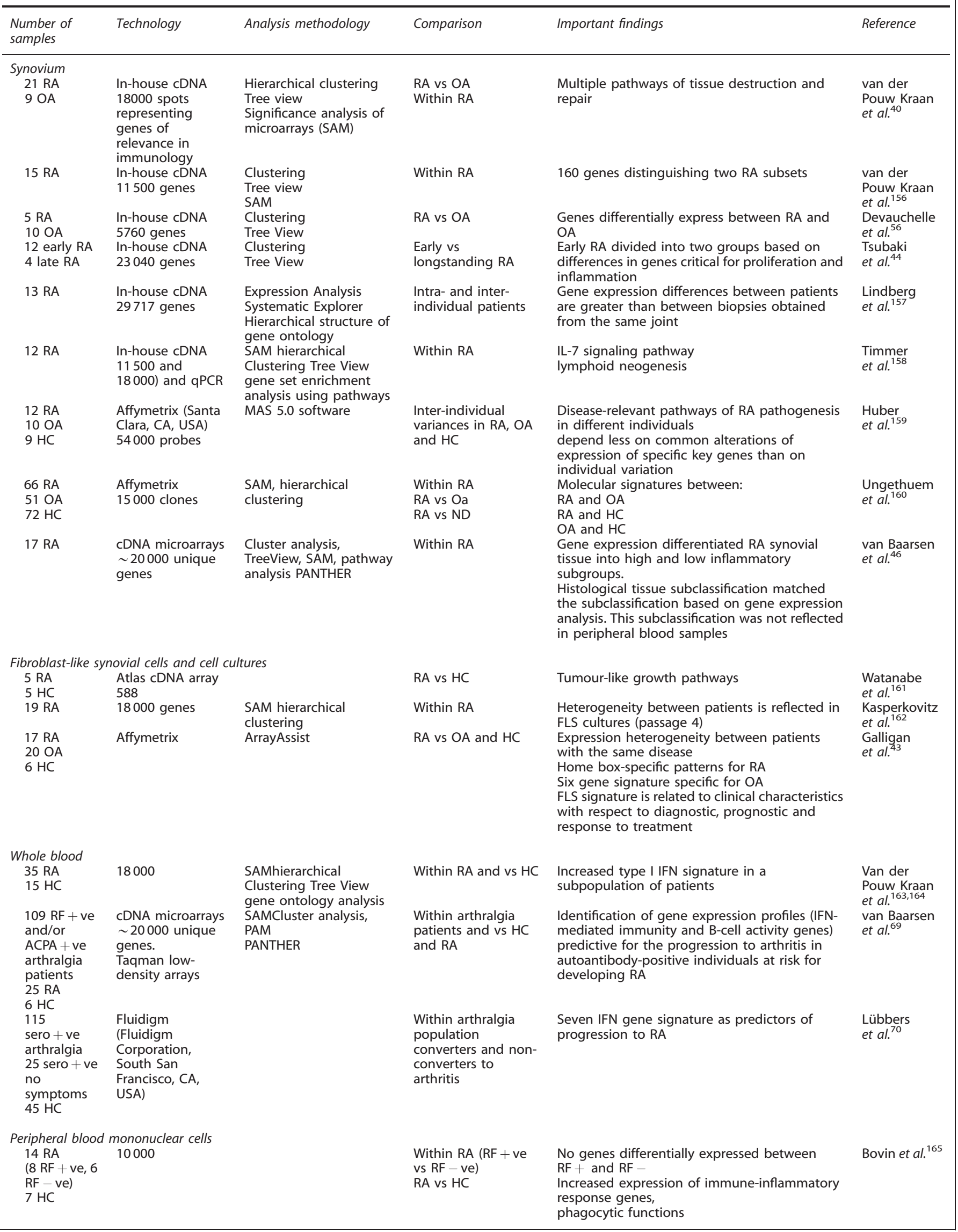




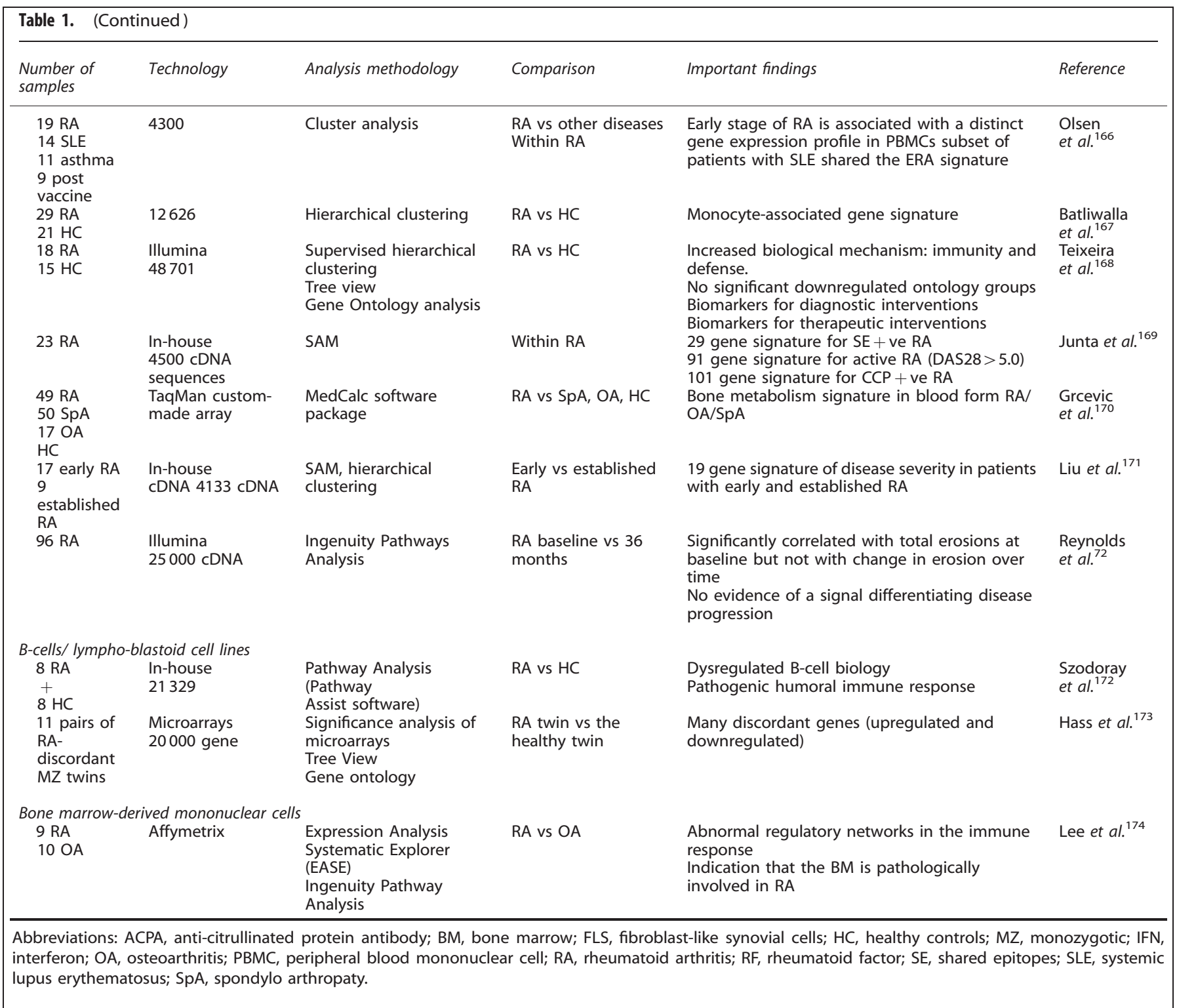

(using micro-array approaches) between RA and osteoarthritis (OA) synovial tissues have shown clear gene signatures differentiating diseases (Table 1). ${ }^{39,40}$ Groups of genes associated with RA clearly identified adaptive inflammatory response-related genes, bone and cartilage degradation enzymes and transcription factors, particularly the STAT1 (signal transducer and activator of transcription 1) pathway. Several other publications also highlighted differences with diseases such as SLE (systemic lupus erythematosus), ankylosing spondylitis or psoriatic arthritis and healthy controls. ${ }^{41-43}$ Importantly, many genes were consistently associated with all diagnostics reflecting inflammation or autoimmune bias rather than disease specificity; others were clearly defining RA-specific events, including interleukin (IL)-7R, matrix metalloproteinase-12 (MMP-12), S100 calcium-binding protein A8, chemokines, chemokine receptors, IL2-inducible T-cell kinase, tumour suppressor p53-binding protein, Homeo box genes, T-cell receptor, regulators of T-cell activation, CD62L Selectin and Runt-related transcription factor 3.

Heterogeneity within RA can already be associated with the progression of disease, and obvious differences have been observed in gene expression between early ( $<12$ months) and late ( $>5$ years) RA synovial tissue samples, ${ }^{44}$ suggesting involvement of different pathophysiological mechanisms over the course of disease. In a specially designed study, gene profiling was applied to identify gene signatures corresponding to different stages of RA comparing synovial biopsies from early RA (disease duration $<12$ months, untreated), longstanding patients RA and control synovia. ${ }^{45}$ Using a small microarray chip containing only 10000 transcripts, early and longstanding RA have distinct molecular signatures with different biological processes participating at different times over the course of the disease, such as host defences, stress responses, T-cell-mediated immunity, tumour suppressor and MHC (major histocompatibility complex) class II-mediated immunity. Additional pathways involved in T-cell activation, endothelial signalling, hypoxia response and plasminogen-activating cascade were also recognized. Similar data were obtained showing differential signatures between low and high inflammatory subsets of RA patients. ${ }^{46}$

Gene expression profiling in established RA further revealed three main types of synovial tissue, the first with mainly $T$ and $B$ cells, antigen-presenting cells and MHC gene signature, a second signature included mainly stromal genes and a third showed 
mixed information. ${ }^{40}$ In relation with the difference in genetic predisposition involving T-cell genes and the autoantibody status, the first group may be speculated to reflect pathology associated with the presence of ACPA although this was not investigated in this paper. Studies combining gene expression and modern imaging could also reveal association between molecular signatures (for example, involving neo-vascularization genes) with signals in power Doppler ultrasound examination, which is predictive of progression towards early RA. ${ }^{47,48}$

\section{Diagnostic, prognostic and preclinical signature in RA}

Diagnostic. Given the destructive nature of RA, early diagnosis and initiation of treatment is highly important. ${ }^{49-51}$ The recently revised diagnostic criteria for RA (European League Against Rheumatism) $2010^{52}$ improved early diagnosis by including ACPA in the criteria but demonstrated even more early disease heterogeneity (only $50 \%$ of patients are positive), stressing the need for other diagnostic biomarkers for ACPA-negative disease. ${ }^{53}$

Using a differential display reverse transcriptase-PCR approach, genes were identified whose expression was different in early inflammatory arthritis biopsies with a diagnosis of RA as opposed to reactive arthritis. ${ }^{54}$ This work primarily highlighted genes that were differentially expressed in T-cell synapse (LCK (lymphocytespecific protein tyrosine kinase), nil2a (Zinc Finger E-box Binding Homeobox 1), T-plastin (plastin isoform T)), notably in relation with anergy, which is a feature of RA (reviewed in Gatzka and Walsh ${ }^{55}$ ). These also included apoptosis-related genes (caspase), calcium signalling (calmodulin, reticulocalmin, calumenin), transcription factors, signal transduction (ADP ribosylation factors) and differentiation (Jagged/Notch), some of which were also expressed in patient's blood cells. Several genes identified in this work (calmodulin, spermine, ADP ribosylation factors, tropomyosin, eukaryotic translation initiation factors) were later confirmed using micro-array technology in synovial tissues ${ }^{56}$ or human blood cells. ${ }^{57}$ The Jagged/Notch differentiation pathway was taken forward and identified clear differences of expression in lymphocytes from RA patients compared with healthy controls and also suggested a role for this pathway in regulatory T-cell activity. ${ }^{58}$

Pratt et al. performed gene expression profiling in separated CD4 + T cells from early inflammatory arthritis patients who later went on to develop RA. ${ }^{59}$ A 12-gene signature distinguishing RA from non-RA patients was derived and validated by quantitative PCR (qPCR) in a second set of patients. Five out of the 12 genes belonged to the IL-6-mediated STAT3 pathway. Interestingly, this signature was valid in both ACPA-positive and -negative inflammatory arthritis patients progressing towards RA, showing an $85 \%$ sensitivity and $75 \%$ specificity for progression. Such $12-$ gene signature, if replicated, may serve as alternative diagnostic biomarker, particularly in seronegative patients.

Preclinical RA. Recognition of the preclinical phase of RA has initiated a whole new field of research aimed at the discovery of predictive biomarkers for the development of arthritis. ${ }^{60}$ Systemic autoimmunity was shown to precede synovitis development. ${ }^{61}$ Indeed, ACPA can be present for years before disease onset. ${ }^{62,63}$ In contrast, synovial abnormalities (that is, increased synovial cellularity) do not occur until symptom onset, ${ }^{61}$ suggesting that other unknown triggers/events/location are driving the inflammatory immune response leading to RA. Alternatively, counter-regulatory mechanisms suppressing disease development despite the presence of autoimmunity may exist. Animal models have suggested that the onset of arthritic disease is preceded by phenotypic changes in draining lymph nodes (LN). ${ }^{64-66}$ Flow cytometry data in LN biopsies from ACPA positive at risk individuals, early arthritis patients and healthy controls suggested increased T-cell activation in early arthritis but not in
ACPA-positive individuals. ${ }^{67,68}$ These data support the rational for further extensive molecular analysis of LN during different phases of (preclinical) arthritis.

Gene expression profiling of peripheral blood cells in arthralgia patients (with confirmed absence of synovitis) and ACPA positivity highlighted a gene signature, including interferon (IFN)-mediated immunity and cytokine/chemokine activity that were specifically observed in at-risk individuals who then went on to develop arthritis. ${ }^{69}$ A second signature, including increased expression of B-cell-specific genes, appeared to be associated with protection from arthritis development. The increased IFN activity in the preclinical phase of RA was confirmed in pre-onset RA patients (samples from the Medical Biobank of Northern Sweden). ${ }^{70}$ The combined analysis of such IFN and B-cell signature in an independent validation cohort of seropositive arthralgia patients confirmed a significant high risk for arthritis development in IFNhigh/B-cell-low profile ( $80 \%$, odds ratio 6.22) and a low risk for IFNlow/B-cell-high profile ( $26 \%$, odds ratio 0.16$)$. To demonstrate clinical utility, a receiver operator characteristic (ROC) curve was constructed for ACPA + /RF + (rheumatoid factor positive) alone and in combination with both signatures. The area under the curve increased substantially when including the IFN and B-cell signatures and the sensitivity to diagnose pre-clinical RA increased (from $16 \%$ to $52 \%$ ) with a cutoff of $94 \%$ specificity. ${ }^{70,71}$

Prognostic. Another important need in RA biomarker research relates to prognostic factors associated with disease progression and development of (new) erosions. Reynold et al. ${ }^{72}$ performed an extensive gene expression profiling study in peripheral blood cells patients with early RA (disease duration $<2$ years, 75\% ACPA + ). Using a 48-K Illumina chip (Illumina, San Diego, CA, USA), gene expression signatures could be associated with severe disease (>10 erosions) at baseline and after 36 months of follow-up; however, no clear expression profile could be associated with disease progression and the development of new erosions. Interestingly, pathway-level analysis suggests a relationship between CTLA-4 (cytotoxic T-lymphocyte antigen 4) T-cell signalling and erosive disease, consistent with a T-cell-mediated pathogenesis early in the disease. In perspective of the genetic association between several T-cell processes and ACPA +/shared epitopes positive disease, ${ }^{73}$ the increase in radiographic progression in these patients is most likely reflected by this gene signature. ${ }^{35,36}$

Gene expression signatures as predictors of treatment response

The expanding range of various biological therapies that is available for RA patients after failure to DMARDs like methotrexate (MTX) has led to the detection of a significant inter-patient heterogeneity in efficacy as well as in the appearance of important adverse effects of these treatments. The pro-inflammatory cytokine tumor necrosis factor $\alpha$ (TNF- $\alpha$ ) has been identified as a pivotal factor in driving inflammation in RA; however, the spectrum of clinical responses to TNF blockade suggest that TNF has an important role in the early phases of disease development (with high response rate) but much less in late RA with the development of alternative TNF-independent pathways.

The first approved target for biological therapies in RA was TNF- $\alpha$. Three antibodies (infliximab, adalimumab and golimumab), one Fab' antibody fragment (certolizumab) and one soluble receptor with affinity for TNF- $\alpha$ and lymphotoxin- $\alpha$ (etanercept) were developed over the years. Other biologicals targeted the cytokine IL-1 (anakinra, soluble IL-1 receptor antagonist), the cytokine receptor for IL-6 (tocilizumab, antibody), the B7 family of costimulatory molecules (abatacept, FclgG1-CTLA4 fusion protein) and the pan B-cell marker CD20 (rituximab, antibody). Biologicals are prescribed on a trial-and-error basis and approximately $30-40 \%$ of patients fail to respond to these therapies. ${ }^{74,75}$ Considering the high cost of biologicals and the possibility of 
severe side effects, the identification of responders and nonresponders to a specific biological would be a major improvement in the management of RA patients. With the goal of optimizing prescription of biologicals for personalized approaches, several groups have studied gene expression profiling of blood cells or synovial biopsies to determine molecular signatures that would predict response to a biological therapy (Table 2).

Methotrexate. The mechanism of action of MTX (a folate antagonist) is still largely unknown, while it is the most commonly used drug for the treatment of RA. Its mechanism of action with respect to the folate metabolism remains elusive in RA. Blits et al. ${ }^{76}$ investigated the cellular pharmacological impact of MTX on peripheral blood cells using the samples obtained from MTX-naive and MTX-treated RA patients as well as from healthy controls. The data revealed that multiple folate metabolism-related genes were consistently and significantly altered between the three groups. Concurrent with an immune activation gene signature, a significant upregulation of folate metabolizing enzymes ( $\gamma$-glutamyl hydrolase, dihydrofolate reductase), and MTX/folate efflux transporters (ABCC2 and ABCC5) was observed in the MTXnaive group compared with healthy controls. Strikingly, MTX treatment normalized such differential gene expression levels to those observed in healthy controls. Hence, these results suggest that under inflammatory conditions basal folate metabolism in blood cells of RA patients is markedly upregulated, whereas MTX treatment restores normal folate metabolism levels. This provides insight into the mechanism of MTX action, paving the way for the development of novel folate metabolism-targeted therapies, although more work in this area will be required to determine if a MTX predictive response signature can be established.

Infliximab. Infliximab was the first biological approved for RA, and as such, it has been mostly studied for the identification of gene expression signatures able to predict its response. In 2006, Lequerré et $a l^{77}$ analyzed gene expression profiles in peripheral blood mononuclear cells (PBMCs) of RA patients before and after infliximab treatment using an arbitrary collection of 12000 probes covering the PBMC transcriptome. They obtained a list of 41 transcripts of which 20 were confirmed by qPCR as predictors of responsiveness with performance of $90 \%$ sensitivity and $70 \%$ specificity. They next determined that eight was the minimal number of transcripts able to predict responsiveness with $80 \%$ sensitivity and $100 \%$ specificity. This publication supported the possibility that a test based on gene expression biomarkers can be designed to optimize prescription of infliximab in RA patients; however, independent validation of these results still remains to be established. The same year, another study was published looking at gene expression profiles in synovial biopsies. Lindberg et al. ${ }^{78}$ analyzed RA patients before and after 2 months infliximab therapy using an in-house microarray. Two hundred and seventy-nine differentially expressed genes were detected between responders and non-responders. At the synovium level, the MMP-3 was significantly upregulated in responders. Two years later, van der Pouw Kraan et al. $^{79}$ analyzed gene expression profiles in RA synovial biopsies using a genome-wide microarray. Their main conclusion was that patients with a high tissue inflammation signature were more likely to benefit from infliximab treatment. In another article by Lindberg et al., ${ }^{80}$ gene expression profiles in RA synovial biopsies were analyzed using an in-house microarray. The presence of lymphocyte aggregates was observed and correlated with response to infliximab confirming previous data obtained using histology. ${ }^{81}$ However, these results also questioned microarray analysis of whole synovial biopsies as an appropriate tool to predict the response to infliximab treatment, by stressing out that the presence of lymphocyte aggregates may represent an important confounding factor in gene expression analysis.
Whole blood appears to be better suited to study gene expression signatures and has then been extensively used to develop predictive biomarkers to infliximab response. In 2010, van Baarsen et al. $^{82}$ performed a qualitative and quantitative pharmacological study of the response to infliximab in whole blood using a genome-wide microarray. In all treated patients, they observed a neutralization of bioactive TNF irrespective of the clinical response with several biological pathways being downregulated (inflammation, angiogenesis, B- and T-cell activation). These results implied a common effect of drug on TNF-driven/-related pathways independently of response; however; no predictive signature could be identified, hence suggesting parallel TNF-dependent and TNF-independent disease mechanisms. Sekiguchi et al. ${ }^{83}$ analyzed gene expression profiles in whole blood using a microarray of 747 genes selected from public database of SAGE (serial analysis of gene expression) for activated $T$ cells, dendritic cells, monocytes and macrophages. Eighteen genes differentially expressed between responders and nonresponders were identified over the course of treatment, but these genes did not predict response before treatment. They, however, reported a clear difference in the kinetics of IFN-related genes during infliximab treatment between responders and nonresponders. A further study measuring 15 gene of a predetermined set of IFN-response genes using real-time PCR in an independent group of patients before and post treatment and showed an increase in type-I IFN response gene expression 1 month after treatment in patients who had a poor clinical response to treatment. ${ }^{84}$ However, again, no association between response and baseline IFN response gene activity could be identified. This signature was therefore not appropriate for evaluation of treatment outcome before infliximab initiation but still may have value very early in the course of treatment.

The first blood-based gene expression signature predicting treatment response was published by Tanino et al. ${ }^{85} \mathrm{~A}$ whole human genome microarray was performed on whole blood at baseline. A list of 10 genes was identified. This 10-biomarker set was then validated with an accuracy of $66.7 \%$. About the same time, Julià et $a .^{86}$ analyzed gene expression of whole blood using a whole human genome microarray. A robust eight-gene predictor signature was identified and applied to an independent validation set of patients. The predictive performance of this signature was $94.4 \%$ sensitivity and $85.7 \%$ specificity. However, also here independent validation of these results still remains to be established.

Other anti-TNF agents. Stuhlmüller et al. ${ }^{87}$ analyzed gene expression profiles in monocytes of RA patients and healthy subjects before and during Adalimumab using a commercial microarray. CD11c was identified as a response to treatment biomarker and was validated by GPCR in a second cohort with $100 \%$ sensitivity and $91.7 \%$ specificity. In another study, Badot et al. $^{88}$ analyzed gene expression profiles before and after adalimumab in synovial biopsies using a commercial microarray. Four hundred and thirty-nine genes were differentially regulated between poor responders as compared with the moderate and good responders and were clustered into two specific pathways: cell division and regulation of immune responses (in particular, cytokines, chemokines and their receptors). A validation study was performed by immunostaining on synovial samples and confirmed the differential baseline expression of five genes, notably CD11c.

Etanercept was evaluated for molecular discrimination between responders and non-responders. Koczan et al. ${ }^{89}$ analyzed gene expression profiles in PBMCs using a commercial microarray. Forty-two genes were differentially expressed. Twenty selected genes were studied by qPCR, and eight were able to discriminate between responders and non-responders. However, the authors concluded that even if gene expression profiling was able to 
Table 2. Gene expression signatures as a tool for treatment outcome prediction

\begin{tabular}{|c|c|c|c|c|c|c|c|}
\hline Drug & Tissue & $\begin{array}{l}\text { Number of } \\
\text { samples }\end{array}$ & Technology & Software & Comparison & Results & Reference \\
\hline \multirow[t]{3}{*}{ MTX } & $\begin{array}{l}\text { CD4+ } \\
\text { T-cells }\end{array}$ & $\begin{array}{l}31 \text { early } \\
\text { RA }\end{array}$ & Illumina & $\begin{array}{l}\text { GeneSpring XI } \\
\text { (Agilent } \\
\text { Technologies, Santa } \\
\text { Clara, CA, USA) }\end{array}$ & $\begin{array}{l}\text { Responders } \\
\text { vs non- } \\
\text { responders }\end{array}$ & $\begin{array}{l}133 \mathrm{CD} 4+\mathrm{T} \text {-cell transcripts } \\
\text { differentially expressed }\end{array}$ & $\begin{array}{l}\text { EWRR } 2013 \\
\text { Abstract Pratt } \\
\text { et al. }{ }^{175}\end{array}$ \\
\hline & $\begin{array}{l}\text { Whole } \\
\text { blood }\end{array}$ & $52 \mathrm{RA}$ & Affymetrix & $\begin{array}{l}\text { Hierarchical } \\
\text { clustering }\end{array}$ & $\begin{array}{l}\text { Responders } \\
\text { and non- } \\
\text { responders }\end{array}$ & $\begin{array}{l}16 \text { gene signature shows clear } \\
\text { discrimination between responders } \\
\text { and non-responders to fMTX } \\
\text { treatment }\end{array}$ & $\begin{array}{l}\text { EWRR } 2013 \\
\text { Abstract Mans } \\
\text { et al. }{ }^{176}\end{array}$ \\
\hline & $\begin{array}{l}\text { Synovial } \\
\text { tissue } \\
\text { fibroblast } \\
\text { cells (FLS) }\end{array}$ & $\begin{array}{l}17 \mathrm{RA} ; 20 \\
\mathrm{OA} ; 6 \mathrm{HC}\end{array}$ & $\begin{array}{l}\text { Affymetrix } \\
47000\end{array}$ & $\begin{array}{l}\text { Hierarchical } \\
\text { clustering, gene } \\
\text { ontology } \\
\text { classification }\end{array}$ & $\begin{array}{l}\text { RA vs OA, } \\
\text { within RA }\end{array}$ & $\begin{array}{l}\text { Different profiles in RA and OA FLS. } \\
\text { Eleven genes elevated in RA on } \\
\text { MTX } 23 \text { genes upregulated in RA } \\
\text { on prednisone therapy. Prednisone } \\
\text { and MTX treatment affected gene } \\
\text { signatures }\end{array}$ & Galligan et al. ${ }^{43}$ \\
\hline Leflunomide & PBMC & $\begin{array}{l}10 \\
\text { patients } \\
\text { with early } \\
\text { RA }\end{array}$ & $\begin{array}{l}\text { DualChip } 282 \\
\text { genes }\end{array}$ & $\begin{array}{l}\text { Hierarchical cluster, } \\
\text { statistical } \\
\text { environment " } \mathrm{R} \text { " }\end{array}$ & $\begin{array}{l}\text { Before vs } 12 \\
\text { weeks after } \\
\text { treatment }\end{array}$ & $\begin{array}{l}\text { Treatment of early RA } \\
\text { Downregulation of many genes }\end{array}$ & Soldana et al. ${ }^{177}$ \\
\hline \multirow[t]{11}{*}{ IFX } & Synovium & $10 \mathrm{RA}$ & $\begin{array}{l}\text { In-house array } \\
30000 \text { cDNA } \\
\text { spots }\end{array}$ & $\begin{array}{l}\text { Hierarchical cluster, } \\
\text { statistical } \\
\text { environment ' } R \text { ' }\end{array}$ & $\begin{array}{l}\text { Before vs } \\
\text { after } 9 \text { week } \\
\text { of } \\
\text { treatment }\end{array}$ & $\begin{array}{l}\text { Genes specifically changed in } \\
\text { patients who have a good response } \\
\text { to IFX treatment }\end{array}$ & Lindberg et al. ${ }^{78}$ \\
\hline & Synovium & $18 \mathrm{RA}$ & $\begin{array}{l}\text { Human cDNA } \\
\text { microarrays } \\
18000\end{array}$ & $\begin{array}{l}\text { Supervized } \\
\text { hierarchical } \\
\text { clustering. Tree view } \\
\text { gene ontology } \\
\text { analysis (PANTHER } \\
\text { database) }\end{array}$ & $\begin{array}{l}\text { Responders } \\
\text { vs non- } \\
\text { responders } \\
\text { to IFX }\end{array}$ & $\begin{array}{l}\text { Patients with high expression of } \\
\text { genes involved in tissue } \\
\text { inflammation before treatment are } \\
\text { more likely to benefit from IFX } \\
\text { therapy }\end{array}$ & $\begin{array}{l}\text { van der Pouw } \\
\text { Kraan et al. }\end{array}$ \\
\hline & $\begin{array}{l}\text { Whole } \\
\text { blood }\end{array}$ & $18 \mathrm{RA}$ & $\begin{array}{l}\text { Customized } \\
\text { microarray } 747 \\
\text { genes }\end{array}$ & Cluster analysis & $\begin{array}{l}\text { Responders } \\
\text { vs non- } \\
\text { responders }\end{array}$ & $\begin{array}{l}\text { Unique set of genes with } \\
\text { differentially expressed in } \\
\text { responders and non-responders to } \\
\text { IFX }\end{array}$ & Sekiguchi et al. ${ }^{83}$ \\
\hline & $\begin{array}{l}\text { Whole } \\
\text { blood }\end{array}$ & $44 \mathrm{RA}$ & Illumina 47000 & $\begin{array}{l}\text { Statistical } \\
\text { environment ' } R \text { ' }\end{array}$ & $\begin{array}{l}\text { Responders } \\
\text { vs non- } \\
\text { responders }\end{array}$ & $\begin{array}{l}\text { Eight-gene signature predicting } \\
\text { response to IFX }\end{array}$ & Julia et al. ${ }^{86}$ \\
\hline & $\begin{array}{l}\text { Whole } \\
\text { blood }\end{array}$ & $\begin{array}{l}\text { Discovery } \\
\text { set } 42 \text { RA, } \\
\text { validation } \\
\text { set } 26 \text { RA }\end{array}$ & Agilent 44000 & Gene ontology & $\begin{array}{l}\text { IFX vs MTX } \\
\text { responders } \\
\text { vs non- } \\
\text { responders }\end{array}$ & $\begin{array}{l}10 \text { gene signature for response } \\
65.4 \% \text { accuracy of prediction }\end{array}$ & Tanino et al. ${ }^{85}$ \\
\hline & PBMC & $13 \mathrm{RA}$ & $\begin{array}{l}\text { In-house } 12000 \\
\text { cDNA }\end{array}$ & $\begin{array}{l}\text { Hierarchical } \\
\text { clustering SAM }\end{array}$ & $\begin{array}{l}\text { Before vs } 3 \\
\text { months } \\
\text { after } \\
\text { responders } \\
\text { vs non- } \\
\text { responders }\end{array}$ & $\begin{array}{l}\text { Predictive signature for IFX/MTX } \\
\text { efficacy } \\
\text { Profile correlating with treatment } \\
\text { response }\end{array}$ & Lequerré et al. ${ }^{77}$ \\
\hline & PBMC & $23 \mathrm{RA}$ & $\begin{array}{l}\text { In-house array } \\
4500 \text { cDNA }\end{array}$ & $\begin{array}{l}\text { Significance analysis } \\
\text { of microarrays (SAM) }\end{array}$ & $\begin{array}{l}\text { IFX treated } \\
\text { vs non- } \\
\text { treated with } \\
\text { IFX }\end{array}$ & $\begin{array}{l}28 \text { signature exclusively expressed } \\
\text { group treated with DMARDs + IFX }\end{array}$ & Junta et al. ${ }^{169}$ \\
\hline & $\begin{array}{l}\text { Synovial } \\
\text { tissue }\end{array}$ & $62 \mathrm{RA}$ & $\begin{array}{l}\text { In-house array } \\
17972 \text { unique } \\
\text { genes }\end{array}$ & $\begin{array}{l}\text { SAM), hierarchical } \\
\text { clusters, gene } \\
\text { ontology }\end{array}$ & $\begin{array}{l}\text { responders } \\
\text { vs non- } \\
\text { responders }\end{array}$ & Feasibility study & Lindberg et al..$^{80}$ \\
\hline & $\begin{array}{l}\text { Whole } \\
\text { blood }\end{array}$ & $\begin{array}{l}\text { Discovery } \\
\text { set } 15 \text { RA, } \\
\text { validation } \\
\text { set } 18 \text { RA }\end{array}$ & $\begin{array}{l}20000 \text { unique } \\
\text { genes }\end{array}$ & $\begin{array}{l}\text { Cluster analysis, Tree } \\
\text { view ontology } \\
\text { (PANTHER) }\end{array}$ & $\begin{array}{l}\text { Before and } \\
1 \text { months } \\
\text { after IFX } \\
\text { treatment }\end{array}$ & $\begin{array}{l}\text { Downregulation of genes in several } \\
\text { biological pathways } \\
\text { Inflammation } \\
\text { Angiogenesis } \\
\text { B- and T-cell activation } \\
\text { Pharmacological response } \\
\text { signature }\end{array}$ & $\begin{array}{l}\text { Van Baarsen } \\
\text { et al. }{ }^{82}\end{array}$ \\
\hline & $\begin{array}{l}\text { Whole } \\
\text { blood }\end{array}$ & $33 \mathrm{RA}$ & $\begin{array}{l}\text { In house: } \\
43000 \text { cDNA } \\
\text { qPCR TaqMan }\end{array}$ & $\begin{array}{l}\text { Tree view Ontology } \\
\text { (PANTHER) }\end{array}$ & & $\begin{array}{l}\text { Candidate } 34 \text { INF gene signature } \\
\text { set Validated } 15 \text { IFN gene set by } \\
\text { Taqman Final } 5 \text { gene set signature }\end{array}$ & $\begin{array}{l}\text { Van Baarsen } \\
\text { et al. }{ }^{84}\end{array}$ \\
\hline & $\begin{array}{l}\text { Peripheral } \\
\text { blood }\end{array}$ & RA & RT-qPCR & $\begin{array}{l}\text { Canonical Variates } \\
\text { Analysis (CVA) }\end{array}$ & $\begin{array}{l}\text { Responders } \\
\text { and non- } \\
\text { responders }\end{array}$ & $\begin{array}{l}30 \text { gene set signature differentiated } \\
\text { responders from non-responders }\end{array}$ & $\begin{array}{l}\text { EWRR } 2013 \\
\text { Abstract } \\
\text { Szekanecz et al. }{ }^{178}\end{array}$ \\
\hline IFX or ADA & $\begin{array}{l}\text { Whole } \\
\text { blood }\end{array}$ & $42 \mathrm{RA}$ & $\begin{array}{l}\text { Affymetrix } \\
17881 \text { genes }\end{array}$ & K-mean clustering & $\begin{array}{l}\text { Responders } \\
\text { vs non- } \\
\text { responders }\end{array}$ & $\begin{array}{l}\text { Eight-gene signature: sensitivity of } \\
71 \% \text {, specificity of } 61 \%\end{array}$ & Toonen et al. ${ }^{101}$ \\
\hline \multirow[t]{2}{*}{ ADA } & Synovium & $25 \mathrm{RA}$ & $\begin{array}{l}\text { Affymetrix } \\
39000 \text { genes }\end{array}$ & & $\begin{array}{l}\text { Baseline vs } \\
12 \text { weeks of } \\
\text { therapy. }\end{array}$ & $\begin{array}{l}\text { Markers of response to TNF } \\
\text { blockade }\end{array}$ & Badot et al. ${ }^{88}$ \\
\hline & Monocytes & $\begin{array}{l}\text { Discovery } \\
\text { set } n=7 \text {, } \\
\text { validation } \\
\text { set } n=77\end{array}$ & Affymetrix & $\begin{array}{l}\text { Hierarchical } \\
\text { clustering; Gene } \\
\text { Ontology; gene } \\
\text { interaction analyses } \\
\text { via Ingenuity } \\
\text { Pathway Analysis }\end{array}$ & $\begin{array}{l}\text { Responders } \\
\text { vs non- } \\
\text { responders }\end{array}$ & $\begin{array}{l}\text { Increased expression of CD11c in } \\
\text { responders to ADA: sensitivity } \\
100 \% \text {; specificity } 91.7 \% \text {; power } \\
99.6 \%\end{array}$ & $\begin{array}{l}\text { Stuhlmuller } \\
\text { et al. }{ }^{87}\end{array}$ \\
\hline ETN or ADA & PBMCs & $8 \mathrm{RA}$ & 25341 genes & SAM & Responder & & Meugnier et al. ${ }^{103}$ \\
\hline
\end{tabular}




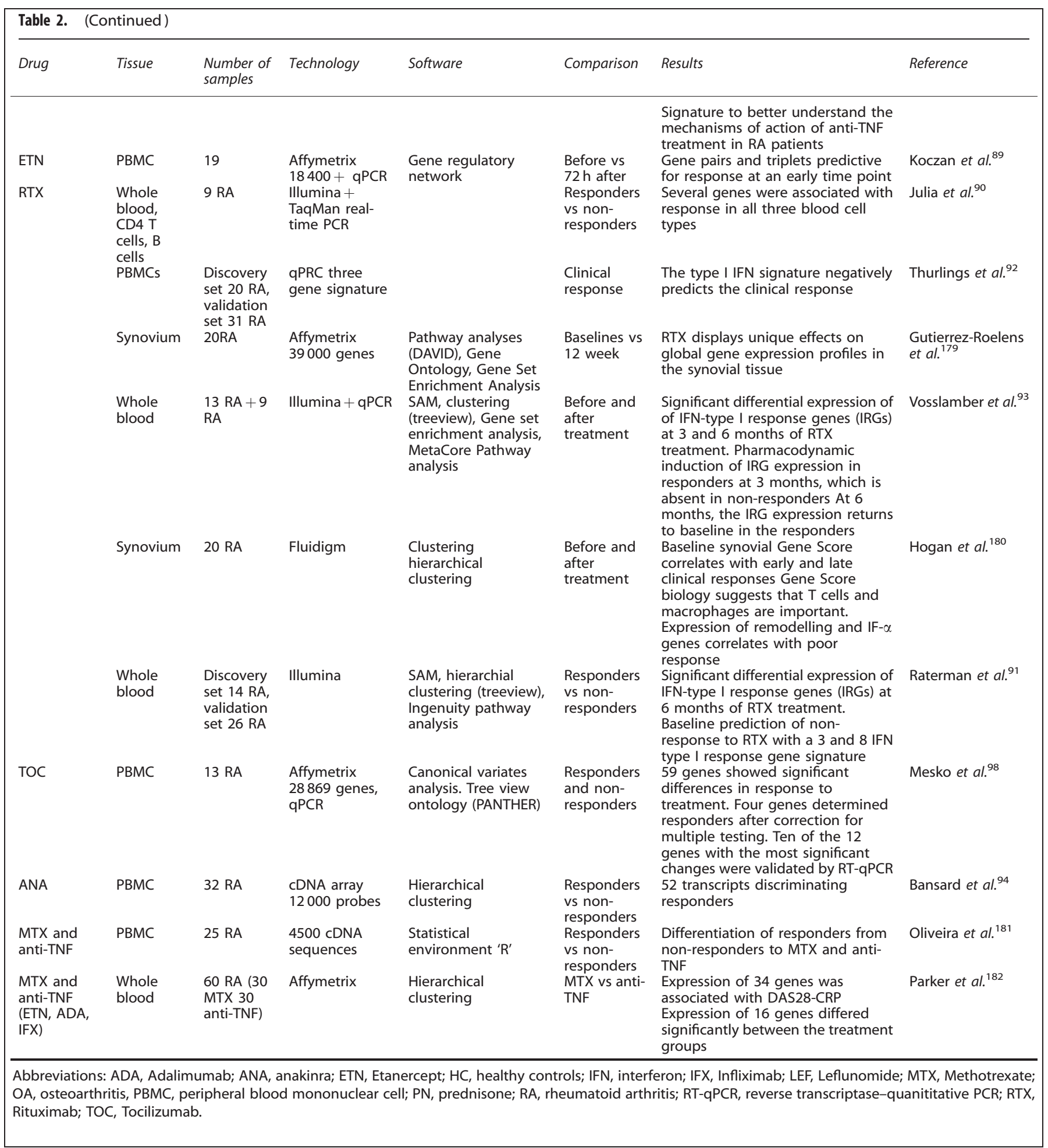

identify genes that were associated with therapeutic outcomes, a gene expression signature at baseline was not reliable in predicting the clinical outcome.

Rituximab. Despite the effective depletion of circulating B cells in nearly all treated patients, $40-50 \%$ of patients do not respond to rituximab treatment. Julià et al. analyzed gene expression profiles in whole blood, CD4 $+\mathrm{T}$ cells, and B cells using a commercial microarray and $\mathrm{qPCR}$ validation. An association of TRAF1 (TNF receptor-associated factor 1) and ARG1 (Arginase 1) expression in whole blood and an association with TLR4 (Toll-like receptor 4) expression in $\mathrm{CD}^{+}{ }^{+} \mathrm{T}$ cells were observed. ${ }^{90}$ They also reported that the serological status of the RA patient has no predictive value for rituximab outcome. Until now, a study wherein the use of these markers is validated is not reported.

Recently, Raterman et al. ${ }^{91}$ analyzed the gene expression profiles in whole blood using a commercial microarray. They identified a type I IFN signature constituting a predicting 
biomarker of response. Good responders had a low or absent IFN response activity at baseline, whereas non-responders display an activated type I IFN system before the start of treatment. Such an association was in line with previous findings, demonstrating that patients with a low IFN signature had a significantly greater reduction of disease activity and more often achieved a significant response. $^{92}$ Clinical utility as predictor of non-response to rituximab was demonstrated in a validation study using ROC curve analysis, based on an optimal set of 3-5 IFN type I genes according to the differential disease activity score. ${ }^{91}$ These results suggest that RA patients with an IFN ${ }^{\text {high }}$ signature represent a different pathogenic subset of patients. Ultimately, these results may provide a biomarker that can be implemented in clinical practice to prescribe the most effective therapy for a particular patient.

Vosslamber et al. ${ }^{93}$ studied the pharmacological effects of rituximab in RA and observed an increase in IFN response activity after treatment in responders, whereas the IFN signature remained stable in non-responders. The IFN signature score returned to baseline values at 6 months after the start of treatment in responders. Thus a pharmacological increase in IFN response activity during rituximab treatment may be necessary for a favourable response and may provide an insight in the biological mechanism underlying such response. These findings notably provide a basis for further study on the role of the IFN signature as a biomarker for effective dosing and timing of treatment, towards patient-tailored treatment and prevention of relapse.

Anakinra. Finally, a gene expression signature for IL-1RA (anakinra) treatment outcome was proposed. Bansard et al. ${ }^{94}$ analyzed gene expression profiles in PBMCs using an in-house microarray. Fifty-two transcripts linked to a gene network focused on IL-1 $\beta$ were identified of which 20 transcripts were selected for qPCR validation. Performance of this 20 transcripts signature for discrimination between responders and non-responders showed $80 \%$ sensitivity and $87.5 \%$ specificity. Seven out of the 20 transcripts were required for an acceptable prediction of response. Two publications sharing exactly the same technical features (same array and batch of PCR-amplified probes for validation) $)^{77,94}$ allowed for a direct comparison between anakinraand infliximab-response signature. No overlap between anakinraand infliximab-selected transcripts was observed, indicating that the selected signature reflects drug specificity rather than pathophysiological mechanisms. However, studies on larger cohorts are needed to validate this hypothesis.

Tocilizumab. Tocilizumab, a humanized monoclonal antibody against the interleukin 6 receptor, is the most recent addition to the panel of antibodies used for the treatment of moderate-tosevere RA. Many clinical studies have been performed so far, and clinical responses were clearly established. ${ }^{95-97}$ So far, one publication reports gene expression for tocilizumab. PBMC gene expression was assessed before and 4 weeks after treatment in a small group of patients. ${ }^{98}$ Four genes (CCDC32, DHFR, EPHA4 and TRAV8-3) were associated with response, and another 59 showed changes with treatment. The four predictive genes for response were not included in any of the published response signatures for antibody-mediated TNF blockade.

Conclusion and future need for validation. Not surprisingly, maybe gene expression signatures for a given clinical end point published to date do not always overlap and have not always been re-validated. The only exceptions were the signatures for progression from preclinical phase of $\mathrm{RA}^{69,70}$ and the prediction of response to rituximab. ${ }^{91,92}$ The often observed lack of reproducibility can be explained by the heterogeneity in technical protocols and microarray platforms used (notably when comparing in-house array to commercial ones), data analysis methods and, most importantly, the choice of clinical assessment of response to treatment (Table 3). Beside technical issues, the heterogeneity of the RA disease itself may be largely responsible for lack of replication in data generated by different groups also taking into consideration the small number of patients included in these studies.

As highlighted in the previous section, genetic risk associated with RA cover over 50-60 genes. $^{28-31}$ Work related to pathogenicity has clearly shown that different pathways can be involved at different stage of the disease evolution. Altogether, reproducibility of data could, maybe, only be expected if patients were analyzed taking into account disease duration, current and past treatment, outcome measures as well as ethnical origin, all of which suggesting the need for large numbers of patients. Finally, lack of reproducibility itself is not uncommon in microarray studies. ${ }^{99}$ A recent publication of interest found an association between a polymorphism in the CD84 gene with response to Etanercept. Utilizing publicly available gene expression data from PBMCs, they found an expression quantitative trait loci between the lead genome-wide association study single-nucleotide polymorphism and CD84 transcripts. Independent analysis of CD84 expression in PBMCs from microarray data demonstrated a non-significant association with response to Etanercept. ${ }^{100}$ Approaches that integrate genotypic and gene expression data may therefore aid in the interpretation of genotype-phenotype relationships.

An external validation study ${ }^{101}$ of existing gene expression signatures for anti-TNF treatments in RA was performed using a genome-wide expression profiling to validate eight previously reported signatures predicting anti-TNF therapy outcome (Lequerré et $a l .^{77}-20$ and 8 genes, Stuhlmüller et $a l^{87}-82,11$ and 3 genes, Julia et $a l^{86}-8$ genes, Tanino et al. ${ }^{85}-8$ genes and Sekiguchi et al. $.^{83}-18$ genes) on whole blood of 42 RA patients before treatment with infliximab or adalimumab. One hundred and thirteen genes differently expressed between responders and non-responders at baseline were identified. Although the signature of Lequerré et al.-20 genes was validated with $71 \%$ sensitivity and $61 \%$ specificity, the robustness of the validation can be debated given that only one algorithm was used to reach that conclusion. Nevertheless, this work clearly demonstrate the need for standardization of any signature across different groups and suggest that proofs of concept exist but that collaboration to perform meta-analysis bridging between different technical platforms will be needed to bring this data into usable biomarker signatures with respect to individual drug (and/or target) specificity.

One major drawback of these studies remains the small number of patients analyzed and the absence of internal validation for most of them. On the other hand, it may be possible to develop a global signature able to predict response to biologicals that share the same target. Bienkowska et al. ${ }^{102}$ analyzed gene expression profiles in whole blood before etanercept, infliximab or adalimumab using a commercial microarray. An eight-gene transcript signature that predict response to three TNF- $\alpha$ blockers was identified with $89 \%$ accuracy (using the Convergent Random Forest approach, for selection of nonredundant molecular features predictive of treatment response, in order to identify the minimum number of features with a maximal predictive power). This observation is in line with data from Meugnier et al. ${ }^{103}$ comparing the effect of etanercept or adalumimab on leukocyte gene expression in RA patients who successfully responded to treatment. ${ }^{102,103}$

miRNA signatures in RA

MicroRNAs (miRNAs) are a recent addition to the gene regulatory mechanisms, ${ }^{104,105}$ and researchers are now exploring the possibility of measuring miRNA in serum samples as well as 
cells. miRNA represent a class of non-coding RNA molecules having pivotal roles in cellular and developmental processes, predicted to affect up to $1 / 3$ of all human protein-encoding genes. miRNAs are potent negative modulators of gene expression involved in several cellular processes. ${ }^{106}$ Compared with other gene regulatory mechanisms such as epigenetic and transcription factors, miRNA-mediated effects allow for the fine tuning of gene expression. Downregulation of gene expression occurs by binding to complementary sites in the $3^{\prime}$ untranslated region of target mRNAs leading to the degradation of mRNA. ${ }^{107}$ miRNAs are considered to exert fine modulation rather than switch on/off mechanisms in the regulation of genes. In addition to regulating biological processes such as development, proliferation, apoptosis, hematopoiesis, angiogenesis, metabolism, anti-viral and immune responses, miRNA research gained widespread attention with the recognition of aberrant expression and/or function in cancer, neurological, cardiovascular, metabolic, neurodegenerative, infectious, chronic inflammatory and autoimmune diseases. ${ }^{108-113}$

In terms of biomarker value, increasing numbers of reports implicate an aberrant expression of certain miRNAs (miR-21, -17, $-92,-15,-16,-18 a,-103,-107-141,-193)$ in response to chemotherapy in different malignancies while, in parallel, they can be used for the classification of patients in different subgroups. ${ }^{114-117}$ A large study on miRNA expression in SLE determined several patterns of differentially expressed miRNAs involved in various biochemical pathways leading to different subtypes of diseases. ${ }^{118}$ miRNA seem to be important players in RA as well. ${ }^{107,119-121}$ They were shown to modulate the inflammatory process in joints (miR-155, miR-146). ${ }^{122,123}$ Further, differential miRNA expression was found in RA compared with OA, in relation to inflammation, and the target genes involved were related to cartilage and bone damage. ${ }^{123}$ Comparing miRNA expression in RA and OA synovial fibroblasts revealed subsets of miRNAs that could potentially be used as clinical markers. ${ }^{124}$ OA fibroblast-like synoviocytes expressed a considerably lower level of miR-124a than RA, with effect on proliferation and chemokine production. ${ }^{125,126}$ In the peripheral blood of RA patients, miR-146, miR-155 and miR-16 were upregulated, in relation to active disease, ${ }^{123,127}$ suggesting a potential as markers of disease activity. ${ }^{112}$ miR-346 negatively regulated the IL-18 response of RA fibroblast, ${ }^{128}$ whereas miR-146a was found to be associated with IL-17 expression in both PBMC and synovium of RA patients. ${ }^{129}$ In turn, TNF and IL-1 were shown to regulate the expression of miR-146a in RA fibroblast-like synoviocytes. ${ }^{130}$ Of note, a methylation-dependent regulation of miR-203 expression in RA synovial fibroblasts has been demonstrated. ${ }^{131}$

Recently, miRNA biomarkers present in plasma with diagnostic potential were also reported ${ }^{121}$ (miR-24, miR-30a-5p and miR$125 a-5 p)$, compared with OA and SLE.

To our knowledge, there has been no study yet investigating whether altered expression of any miRNAs is involved in RA patients' response to therapy; however, these will most likely become available in the near future. Having defined such signature will allow either these miRNAs or their corresponding gene targets to be examined for any potential correlation with response to anti-TNF or other biologicals treatment in RA. These results will clearly uphold the basic studies associating gene polymorphisms and gene expression with the response to treatment, towards an improved personalized medicine approach in RA.

Ethical issues associated with development of gene expression signature in RA: towards personalized medicine

Gene expression signatures represent molecular fingerprints that underlie human disease, with the potential to suggest an outcome with the highest probability of achievement. ${ }^{132,133}$ The use of molecular tools raises several ethical and legal concerns. Not all
Table 3. Important records for successful comparison between gene expression studies

\begin{tabular}{|c|c|}
\hline Study design & $\begin{array}{l}\text { 1. Studied populations } \\
\text { (a) Demographics (age, gender, race) } \\
\text { (b) Biological groupings between } \\
\text { subjects (health or disease symptom } \\
\text { duration and so on) } \\
\text { (c) Diagnostic criteria, stratification, } \\
\text { concomitant medication } \\
\text { 2. Differences in clinical management of } \\
\text { the patients (that is, measurements in } \\
\text { treatment response) } \\
\text { 3. Power analysis and confidence } \\
\text { 4. No validation/replication set of patients } \\
\text { included in analysis }\end{array}$ \\
\hline \multicolumn{2}{|l|}{ Technical aspects } \\
\hline $\begin{array}{l}\text { Sample collection } \\
\text { and processing }\end{array}$ & $\begin{array}{l}\text { 5. Methods and timing of sample } \\
\text { collection and processing } \\
\text { (a) Blood tubes PAXgene vs } \\
\text { Tempus vs PBMC } \\
\text { (b) Influence of circadian rhythm } \\
\text { (c) Effect of tissue handling (ex vivo cell- } \\
\text { isolation procedures may activate } \\
\text { some cell types) }\end{array}$ \\
\hline Sample selection & $\begin{array}{l}\text { 6. Cell source } \\
\text { (a) Blood vs tissue } \\
\text { (b) Whole blood vs PBMCs vs isolated } \\
\text { sub-populations of immune cells } \\
\text { (c) Tissue anatomical differences } \\
\text { (d) Tissue-heterogeneity of cell types } \\
\text { within biopsy (synovial tissue, } \\
\text { synoviocytes, tissue architecture } \\
\text { complexity) }\end{array}$ \\
\hline $\begin{array}{l}\text { Analysis } \\
\text { methodology }\end{array}$ & $\begin{array}{l}\text { 7. Overlap between sets of genes } \\
\text { investigated in different studies } \\
\text { 8. Methods for the final selection of } \\
\text { predictive genes (as an outcome of the } \\
\text { study) } \\
\text { 9. Different algorithms used to select } \\
\text { genes for investigation }\end{array}$ \\
\hline $\begin{array}{l}\text { Array selection and } \\
\text { preparation }\end{array}$ & $\begin{array}{l}\text { 10. Technological variation (array platform): } \\
\text { custom made (in-house made) vs } \\
\text { commercially available arrays }\end{array}$ \\
\hline Hybridization & $\begin{array}{l}\text { 11. Hybridization, mixing, washing, } \\
\text { drying, QC }\end{array}$ \\
\hline
\end{tabular}

Abbreviations: PBMC, peripheral blood mononuclear cell; QC, quality control.

clinical studies involve the same risks; the number of ethical and legal issues in biomedical research, therefore, depends on the nature of the test/data involved. Long-term implications for health were associated with genetic data; ${ }^{134}$ however, data derived from transcriptome analysis, as well as proteomics and metabolomics, carry less ethically charged information than measures of the genome. Hence, the testing of gene expression appears much less problematic in terms of ethics due to the fact that mRNA gene expression analysis is functionally close to any other biochemical biomarker or dynamic phenotype and is not a permanently affixed label to its carrier. ${ }^{135}$ Therefore, identifiable data are less sensitive.

The initial hope that the experiment will benefit the patient need to be carefully addressed, especially when very sick patients are eager to accept the promise of an unproven test. How we should use gene expression profiling to guide decisions on preventative and therapeutic intervention without over treating (thus probably leading to adverse effects) remains difficult to regulate, and experience will most likely direct future guidelines, especially considering the potential conflict of interest between 
commercial companies offering preclinical testing and those offering interventions. Once the initial research phase has validated the signature, it becomes essential to determine 'who' should participate in the final decision to treat the patient (in the case of a therapy outcome signature). Hence, there must be reasonable scientific evidence that the patient will benefit from the test being performed, as well as acceptable risks that one will not. This involves understanding and explaining the strengths and limitations of the signature to the patients that is critical to the formulation of information leaflet for safe and effective use of the test results. ${ }^{136}$ Result disclosure to patients participating to that research phase must also be resolved from the initial consent. An important consideration is the problem of constructing an accurate prediction rule, and overly optimistic estimations of prediction performance must be avoided. ${ }^{136}$ Patients need to be aware of real expectations. Indeed, the concept of significance of a test is unknown to the people who are tested, and they often literarily do not understand what they are getting into, hence it may carry a psychosocial impact the person is not prepared for.

Considering that the costs of obtaining data for gene expression microarray tend to be very expensive and could be reduced by merging existing data sets, data sharing, therefore, appears essential to allow the development and validation of gene expression signature. Similarly to informed consent, datasharing approaches must also be established initially to favour collaborative work. In terms of developing a predictive tool, resultsharing approaches will have to be used. ${ }^{132}$

\section{The future of gene expression tests in RA}

It is clear from the above review that gene expression profiling offers great potential for understanding RA biology as well as for patient management and personalization of treatment decisions. It usually takes many years for new biomarkers or sets of biomarkers to reach clinics, starting from basic research biomarker discovery followed by validation, clinical utility evaluation, manufacturing development and final approval by regulatory authorities. This is further complicated by the difference in legislation between European Union, United States and other part of the world, although some recent approaches are aiming to accelerate translation of biomarker from bench to clinic. ${ }^{135}$ In the case of novel gene expression-based test, there is a further need for clear and specific regulations. The Minimum Information About a Microarray Experiment (MIAME) guidelines were developed by the Microarray Gene Expression Data Society and published in 2001 with such a goal in mind. ${ }^{137}$ The MIAME guidelines lay out the minimum standards needed to ensure that an experiment using microarrays can be properly and independently interpreted. $^{138}$ Several clinical application tests using gene expression profiling assays are already available on the market. It seems, however, that these commercialized multi-gene prognostic and predictive tests are so far limited to the field of breast cancer and other cancer diagnostics. Some are FDA approved and already support clinicians in prediction of tumour reoccurrence and making decisions in selection of treatment (MammaPrint, Oncotype DX), ${ }^{139-141}$ but for others the evidence supporting clinical utility is still limited (THEROS Breast Cancer Index, Aviara MGI, Mammostrat, BreastOncPx and PAM50). ${ }^{21,142-149}$ Hence, none of these are currently recommended for the evaluation of breast cancer recurrence risk by national guidelines (that is, National Comprehensive Cancer Network or American Society of Clinical Oncology), and these tests remain considered as investigational. Recently, new tests emerged for acute heart allograft rejection (Allomap XDx, FDA approved) ${ }^{24,150}$ for diagnosis of obstructive CAD (obstructive coronary artery disease) in patients with chest discomfort (Corus CAD) ${ }^{151,152}$ and for the detection of Alzheimer's disease. ${ }^{153,154}$ As all novel biomarkers, it will take time for these to be adopted in daily clinical practice despite recommendation and guideline being published by professional association. ${ }^{155}$

Thus, there is precedent that could be applied to RA and other autoimmune diseases. The Rheumatology community is therefore facing a challenge to pool together the necessary resources and to use the available information already collected to reach appropriate conclusions and proceed with further validation, which is necessary to reach the next level. Considering the impact of RA on our modern society and the large amount of data already available, regulatory authorities such as the European Commission (FP7 and 2020 Horizon programs) as well as industry (Innovative Medicine Initiative) have developed grant schemes to overcome this challenge. Clear guidelines and standardization for such new technology have also been developed (MIAME guidelines). ${ }^{138}$ The successful translation of microarray data into clinical use in cancer provides a strong rational for a similar approach to improve the care of patients in rheumatology.

\section{CONFLICT OF INTEREST}

The authors declare no conflict of interest.

\section{ACKNOWLEDGMENTS}

This work was supported by the IMI-funded project BeTheCure, 115142-2.

\section{REFERENCES}

1 Reis-Filho JS, Pusztai L. Gene expression profiling in breast cancer: classification prognostication, and prediction. Lancet 2011; 378: 1812-1823.

2 Sørlie T, Wang Y, Xiao C, Johnsen H, Naume B, Samaha RR et al. Distinct molecular mechanisms underlying clinically relevant subtypes of breast cancer: gene expression analyses across three different platforms. BMC Genomics 2006; 7: 127 .

3 Colombo PE, Milanezi F, Weigelt B, Reis-Filho JS. Microarrays in the 2010s: the contribution of microarray-based gene expression profiling to breast cancer classification, prognostication and prediction. Survival 2011; 5: 5.

4 Kreike B, Halfwerk H, Kristel P, Glas A, Peterse H, Bartelink $H$ et al. Gene expression profiles of primary breast carcinomas from patients at high risk for local recurrence after breast-conserving therapy. Clin Cancer Res 2006; 12 5705-5712.

5 Glas AM, Kersten MJ, Delahaye L, Witteveen AT, Kibbelaar RE, Velds A et al. Gene expression profiling in follicular lymphoma to assess clinical aggressiveness and to guide the choice of treatment. Blood 2005; 105: 301-307.

6 Beer DG, Kardia SLR, Huang CC, Giordano TJ, Levin AM, Misek DE et al. Geneexpression profiles predict survival of patients with lung adenocarcinoma. Nat Med 2002; 8: 816-824

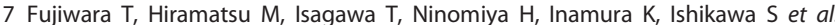
ASCL1-coexpression profiling but not single gene expression profiling defines lung adenocarcinomas of neuroendocrine nature with poor prognosis. Lung Cancer 2012; 75: 119-125.

8 Yeoh EJ, Ross ME, Shurtleff SA, Williams WK, Patel D, Mahfouz R et al. Classification, subtype discovery, and prediction of outcome in pediatric acute lymphoblastic leukemia by gene expression profiling. Cancer Cell 2002; 1: 133-144.

9 Alizadeh AA, Eisen MB, Davis RE, Ma C, Lossos IS, Rosenwald A et al. Distinct types of diffuse large B-cell lymphoma identified by gene expression profiling. Nature 2000; 403: 503-511.

10 Shipp MA, Ross KN, Tamayo P, Weng AP, Kutok JL, Aguiar RC et al. Diffuse large B-cell lymphoma outcome prediction by gene-expression profiling and supervised machine learning. Nat Med 2002; 8: 68-74.

11 Gutiérrez-García G, Cardesa-Salzmann T, Climent F, González-Barca E, Mercadal S, Mate $\mathrm{JL}$ et al. Gene-expression profiling and not immunophenotypic algorithms predicts prognosis in patients with diffuse large B-cell lymphoma treated with immunochemotherapy. Blood 2011; 117: 4836-4843.

12 Puyo S, Houede N, Kauffmann A, Richaud P, Robert J, Pourquier PA. Gene expression signature predicting high grade prostate cancer response to Oxaliplatin. Mol Pharmacol 2012; 82: 1205-1216.

13 Volinia S, Galasso M, Sana ME, Wise TF, Palatini J, Huebner K et al. Breast cancer signatures for invasiveness and prognosis defined by deep sequencing of microRNA. Proc Natl Acad Sci 2012; 109: 3024-3029.

14 Azim Jr HA, Michiels S, Bedard PL, Singhal SK, Criscitiello C, Ignatiadis M et al. Elucidating prognosis and biology of breast cancer arising in young women using gene expression profiling. Clin Cancer Res 2012; 18: 1341-1351. 
15 Mannelqvist M, Stefansson IM, Bredholt G, Hellem Bø T, Øyan AM, Jonassen I et al. Gene expression patterns related to vascular invasion and aggressive features in endometrial cancer. Am J Pathol 2011; 178: 861-871.

16 Salazar R, Roepman P, Capella G, Moreno V, Simon I, Dreezen C et al. Gene expression signature to improve prognosis prediction of stage II and III colorectal cancer. J Clin Oncol 2011; 29: 17-24.

17 Chang SH, Suh KS, Yi NJ, Lee KH, Kim BY, Jang JJ. Predicting the prognosis of hepatocellular carcinoma using gene expression. J Surg Res 2011; 171: 524-531.

18 Villanueva A, Hoshida Y, Battiston C, Tovar V, Sia D, Alsinet C et al. Combining clinical, pathology, and gene expression data to predict recurrence of hepatocellular carcinoma. Gastroenterology 2011; 140: e1502.

19 Brettingham-Moore KH, Duong CP, Heriot AG, Thomas RJS, Phillips WA. Using gene expression profiling to predict response and prognosis in gastrointestinal cancers-the promise and the perils. Ann Surg Oncol 2011; 18: 1484-1491.

20 Lu X, Wang ZC, Iglehart JD, Zhang X, Richardson AL. Predicting features of breast cancer with gene expression patterns. Breast Cancer Res Treat 2008; 108 : 191-201.

21 Sotiriou C, Wirapati P, Loi S, Harris A, Fox S, Smeds J et al. Gene expression profiling in breast cancer: understanding the molecular basis of histologic grade to improve prognosis. J Natl Cancer Inst 2006; 98: 262-272.

22 Wirapati P, Sotiriou C, Kunkel S, Farmer P, Pradervand S, Haibe-Kains B et al. Meta-analysis of gene expression profiles in breast cancer: toward a unified understanding of breast cancer subtyping and prognosis signatures. Breast Cancer Res 2008; 10: R65.

23 Muffak-Granero K, Bueno P, Olmedo C, Comino A, Hassan L, Garcia-Alcalde F et al. Study of gene expression profile in liver transplant recipients with hepatitis $C$ virus. Transplant Proc 2008; 40: 2971-2974.

24 Pham MX, Teuteberg JJ, Kfoury AG, Starling RC, Deng MC, Cappola TP et al. Gene-expression profiling for rejection surveillance after cardiac transplantation. N Engl J Med 2010; 362: 1890-1900.

25 Crespo-Leiro M, Stypmann J, Zuckermann A, Bara C, Ross H, Parameshwar J et al. Utility of Gene Expression Profiling Test (GEP) Score instability to predict future clinical outcomes in heart transplant: results from the CARGO 2 European-Based Multicenter Trial. J Heart Lung Transplant 2013; 32: S113-S114.

26 Deng M, Eisen H, Mehra M, Billingham M, Marboe C, Berry G et al. Noninvasive discrimination of rejection in cardiac allograft recipients using gene expression profiling. Am J Transplant 2006; 6: 150-160.

27 Pham MX, Deng MC, Kfoury AG, Teuteberg JJ, Starling RC, Valantine H. Molecular testing for long-term rejection surveillance in heart transplant recipients: design of the Invasive Monitoring Attenuation Through Gene Expression (IMAGE) trial. J Heart Lung Transplant 2007; 26: 808-814.

28 McAllister K, Eyre S, Orozco G. Genetics of rheumatoid arthritis: GWAS and beyond. Open Access Rheumatol Res Rev 2011; 3: 1-16.

29 Suzuki A, Kochi Y, Okada Y, Yamamoto K. Insight from genome-wide association studies in rheumatoid arthritis and multiple sclerosis. FEBS letters 2011; 585: 3627-3632.

30 Zhernakova A, Stahl EA, Trynka G, Raychaudhuri S, Festen EA, Franke L et al. Meta-analysis of genome-wide association studies in celiac disease and rheumatoid arthritis identifies fourteen non-HLA shared loci. PLoS Genet 2011; 7 e1002004.

31 Eyre S, Bowes J, Diogo D, Lee A, Barton A, Martin P et al. High-density genetic mapping identifies new susceptibility loci for rheumatoid arthritis. Nat Genet 2012; 44: 1336-1340.

32 Klareskog L, Catrina Al, Paget S. Rheumatoid arthritis. Lancet 2009; 373: 659-672.

33 Viatte S, Plant D, Bowes J, Lunt M, Eyre S, Barton A et al. Genetic markers of rheumatoid arthritis susceptibility in anti-citrullinated peptide antibody negative patients. Ann Rheum Dis 2012; 71: 1984-1990.

34 Kurreeman F, Liao K, Chibnik L, Hickey B, Stahl E, Gainer V et al. Genetic basis of autoantibody positive and negative rheumatoid arthritis risk in a multi-ethnic cohort derived from electronic health records. Am J Hum Genet 2011; 88: 57-69.

35 Berglin E, Johansson T, Sundin U, Jidell E, Wadell G, Hallmans G et al. Radiological outcome in rheumatoid arthritis is predicted by presence of antibodies against cyclic citrullinated peptide before and at disease onset, and by IgA-RF at disease onset. Ann Rheum Dis 2006; 65: 453-458.

36 Del Amo NDV, Bosch RI, Manteca CF, Polo RG, Cortina EL. Anti-cyclic citrullinated peptide antibody in rheumatoid arthritis: relation with disease aggressiveness. Clin Exp Rheumatol 2006; 24: 281-286.

37 van der Helm-vanMil AHM, le Cessie S, van Dongen H, Breedveld FC, Toes REM, Huizinga TWJ. A prediction rule for disease outcome in patients with Recent-onset undifferentiated arthritis: how to guide individual treatment decisions. Arthritis Rheum 2007; 56: 433-440.

38 van Dongen H, van Aken J, Lard LR, Visser K, Ronday HK, Hulsmans HMJ et al. Efficacy of methotrexate treatment in patients with probable rheumatoid arthritis: A double-blind, randomized, placebo-controlled trial. Arthritis Rheum 2007; 56: 1424-1432.

39 van der Pouw Kraan TC, van Gaalen FA, Huizinga TW, Pieterman E, Breedveld FC, Verweij CL. Discovery of distinctive gene expression profiles in rheumatoid synovium using cDNA microarray technology: evidence for the existence of multiple pathways of tissue destruction and repair. Genes Immun 2003; 4: 187-196.

40 van der Pouw Kraan TCTM, van Gaalen FA, Kasperkovitz PV, Verbeet NL, Smeets TJM, Kraan MC et al. Rheumatoid arthritis is a heterogeneous disease: evidence for differences in the activation of the STAT-1 pathway between rheumatoid tissues. Arthritis Rheum 2003; 48: 2132-2145.

41 Batliwalla FM, Baechler EC, Xiao X, Li W, Balasubramanian S, Khalili $\mathrm{H}$ et al. Peripheral blood gene expression profiling in rheumatoid arthritis. Genes Immun 2005; 6: 388-397.

42 Toukap AN, Galant C, Theate I, Maudoux A, Lories R, Houssiau F et al. Identification of distinct gene expression profiles in the synovium of patients with systemic lupus erythematosus. Arthritis Rheum 2007; 56: 1579-1588.

43 Galligan CL, Baig E, Bykerk V, Keystone EC, Fish EN. Distinctive gene expression signatures in rheumatoid arthritis synovial tissue fibroblast cells: correlates with disease activity. Genes Immun 2007; 8: 480-491.

44 Tsubaki T, Arita N, Kawakami T, Shiratsuchi T, Yamamoto H, Takubo N et al. Characterization of histopathology and gene-expression profiles of synovitis in early rheumatoid arthritis using targeted biopsy specimens. Arthritis Res Ther 2005; 7: R825-R836.

45 Lequerre T, Bansard C, Vittecoq O, Derambure C, Hiron M, Daveau M et al. Early and long-standing rheumatoid arthritis: distinct molecular signatures identified by gene-expression profiling in synovia. Arthritis Res Ther 2009; 11: R99.

46 van Baarsen LG, Wijbrandts CA, Timmer TC, van der Pouw Kraan TC, Tak PP, Verweij CL. Synovial tissue heterogeneity in rheumatoid arthritis in relation to disease activity and biomarkers in peripheral blood. Arthritis Rheum 2010; 62: 1602-1607

47 van de Stadt $L A$, Bos $W H$, Reynders MM, Wieringa $H$, Turkstra F, van der Laken CJ et al. The value of ultrasonography in predicting arthritis in auto-antibody positive arthralgia patients: a prospective cohort study. Arthritis Res Ther 2010; 12: R98.

48 Freeston JE, Wakefield RJ, Conaghan PG, Hensor EM, Stewart SP, Emery P. A diagnostic algorithm for persistence of very early inflammatory arthritis: the utility of power Doppler ultrasound when added to conventional assessment tools. Ann Rheum Dis 2010; 69: 417-419.

49 Mottonen T, Hannonen P, Korpela M, Nissila M, Kautiainen $\mathrm{H}$, llonen J et al. Delay to institution of therapy and induction of remission using single-drug or combination-disease-modifying antirheumatic drug therapy in early rheumatoid arthritis. Arthritis Rheum 2002; 46: 894-898.

50 O'Dell JR. Treating rheumatoid arthritis early: a window of opportunity? Arthritis Rheum 2002; 46: 283-285.

51 Quinn M, Conaghan P, Emery P. The therapeutic approach of early intervention for rheumatoid arthritis: what is the evidence? Rheumatology 2001; 40: 1211-1220.

52 Aletaha D, Neogi T, Silman AJ, Funovits J, Felson DT, Bingham 3rd CO et al. 2010rheumatoid arthritis classification criteria: an American College of Rheumatology/European League Against Rheumatism collaborative initiative. Ann Rheum Dis 2010; 69: 1580-1588.

53 van der Helm-van Mil AH, Huizinga TW. The 2010 ACR/EULAR criteria for rheumatoid arthritis: do they affect the classification or diagnosis of rheumatoid arthritis? Ann Rheum Dis 2012; 71: 1596-1598.

54 Ali M, Ponchel F, Wilson KE, Francis MJD, Wu X, Verhoef A et al. Rheumatoid arthritis synovial $T$ cells regulate transcription of several genes associated with antigen-induced anergy. J Clin Invest 2001; 107: 519-519.

55 Gatzka M, Walsh CM. Apoptotic signal transduction and T cell tolerance. Autoimmunity 2007; 40: 442-452.

56 Devauchelle V, Marion S, Cagnard N, Mistou S, Falgarone G, Breban M et al. DNA microarray allows molecular profiling of rheumatoid arthritis and identification of pathophysiological targets. Genes Immun 2004; 5: 597-608.

57 Edwards CJ, Feldman JL, Beech J, Shields KM, Stover JA, Trepicchio WL et al. Molecular profile of peripheral blood mononuclear cells from patients with rheumatoid arthritis. Mol Med 2007; 13: 40-58.

$58 \mathrm{Ng} \mathrm{WF}$, Duggan PJ, Ponchel F, Matarese G, Lombardi G, Edwards AD et al. Human CD4 + CD25 + cells: a naturally occurring population of regulatory T cells. Blood 2001; 98: 2736-2744.

59 Pratt AG, Swan DC, Richardson S, Wilson G, Hilkens CM, Young DA et al. A CD4 $T$ cell gene signature for early rheumatoid arthritis implicates interleukin 6-mediated STAT3 signalling, particularly in anti-citrullinated peptide antibodynegative disease. Ann Rheum Dis 2012; 71: 1374-1381.

60 Gerlag DM, Raza K, van Baarsen LG, Brouwer E, Buckley CD, Burmester GR et al. EULAR recommendations for terminology and research in individuals at risk 
of rheumatoid arthritis: report from the Study Group for Risk Factors for Rheumatoid Arthritis. Ann Rheum Dis 2012; 71: 638-641.

61 van de Sande M, De Hair M, Van der Leij C, Klarenbeek P, Bos W, Smith M et al. Different stages of rheumatoid arthritis: features of the synovium in the preclinical phase. Ann Rheum Dis 2011; 70: 772-777.

62 Rantapaa-Dahlqvist S, De Jong BA, Berglin E, Hallmans G, Wadell G, Stenlund $\mathrm{H}$ et al. Antibodies against cyclic citrullinated peptide and IgA rheumatoid factor predict the development of rheumatoid arthritis. Arthritis Rheum 2003; 48: 2741-2749.

63 Nielen $M$, van Schaardenburg $D$, Reesink $H$, van de Stadt $R$, van der HorstBruinsma I, de Koning $\mathrm{M}$ et al. Specific autoantibodies precede the symptoms of rheumatoid arthritis: a study of serial measurements in blood donors. Arthritis Rheum 2004; 50: 380-386.

64 Wooley PH, Whalen JD. Pristane-induced arthritis in mice. III. Lymphocyte phenotypic and functional abnormalities precede the development of pristaneinduced arthritis. Cell Immunol 1991; 138: 251-259.

65 Rodríguez-Palmero M, Pelegrí C, Ferri MJ, Castell M, Franch À, Castellote C. Alterations of lymphocyte populations in lymph nodes but not in spleen during the latency period of adjuvant arthritis. Inflammation 1999; 23: 153-165.

66 Li J, Kuzin I, Moshkani S, Proulx ST, Xing L, Skrombolas D et al. Expanded CD23 + /CD21 hi B cells in inflamed lymph nodes are associated with the onset of inflammatory-erosive arthritis in TNF-transgenic mice and are targets of antiCD20 therapy. J Immunol 2010; 184: 6142-6150.

67 de Hair MJ, Harty LC, Gerlag DM, Pitzalis C, Veale DJ, Tak PP. Synovial tissue analysis for the discovery of diagnostic and prognostic biomarkers in patients with early arthritis. J Rheumatol 2011; 38: 2068-2072.

68 van Baarsen LGM, De Hair M, Ramwadhdoebe T, van de Sande M, Zijlstra I, Maas $\mathrm{M}$ et al. Investigating the cellular composition of lymph nodes in preclinical and early inflammatory arthritis: a feasibility study. Ann Rheum Dis 2012; 71(Suppl 1): A20-A20.

69 van Baarsen LG, Bos WH, Rustenburg F, van der Pouw Kraan TC, Wolbink GJ, Dijkmans BA et al. Gene expression profiling in autoantibody-positive patients with arthralgia predicts development of arthritis. Arthritis Rheum 2010; 62 694-704.

70 Lübbers J, Brink M, van de Stadt LA, Vosslamber S, Wesseling JG, van Schaardenburg $D$ et al. The type I IFN signature as a biomarker of preclinical rheumatoid arthritis. Ann Rheum Dis 2013; 72: 776-780.

71 Lubbers J, van de Stadt LA, Vosslamber S, Wesseling JG, Oztürk S, van Schaardenburg $D$ et al. A1. 7 interferon and B-cell gene signatures contribute to diagnosis of pre-clinical rheumatoid arthritis. Ann Rheum Dis 2013; 72(Suppl 1): A3.

72 Reynolds RJ, Cui X, Vaughan LK, Redden DT, Causey Z, Perkins E et al. Gene expression patterns in peripheral blood cells associated with radiographic severity in African Americans with early rheumatoid arthritis. Rheumatol Int 2012; 33: 129-137.

73 Plenge RM, Cotsapas C, Davies L, Price AL, de Bakker PIW, Maller J et al. Two independent alleles at $6 \mathrm{q} 23$ associated with risk of rheumatoid arthritis. Nat Genet 2007; 39: 1477-1482.

74 Lipsky P, van der Heijde D, St. Clair E, Furst D, Breedveld F, Kalden J et al. Infliximab and methotrexate in the treatment of rheumatoid arthritis. $N$ Engl $J$ Med 2000; 343: 1594-1602.

75 Zink A, Strangfeld A, Schneider M, Herzer P, Hierse F, Stoyanova-Scholz M et al. Effectiveness of tumor necrosis factor inhibitors in rheumatoid arthritis in an observational cohort study: comparison of patients according to their eligibility for major randomized clinical trials. Arthritis Rheum 2006; 54: 3399-3407.

76 Blits M, Jansen G, Assaraf YG, van de Wiel MA, Lems WF, Nurmohamed MT et al. Methotrexate normalizes up-regulated folate pathway genes in rheumatoid arthritis. Arthritis Rheum 2013; 65: 2791-2802.

77 Lequerré T, Gauthier-Jauneau AC, Bansard C, Derambure C, Hiron M, Vittecoq O et al. Gene profiling in white blood cells predicts infliximab responsiveness in rheumatoid arthritis. Arthritis Res Ther 2006; 8: R105.

78 Lindberg J, af Klint E, Catrina Al, Nilsson P, Klareskog L, Ulfgren AK et al. Effect of infliximab on mRNA expression profiles in synovial tissue of rheumatoid arthritis patients. Arthritis Res Ther 2006; 8: R179.

79 van der Pouw Kraan TC, Wijbrandts CA, van Baarsen LG, Rustenburg F, Baggen JM, Verweij CL et al. Responsiveness to anti-tumour necrosis factor alpha therapy is related to pre-treatment tissue inflammation levels in rheumatoid arthritis patients. Ann Rheum Dis 2008; 67: 563-566.

80 Lindberg J, Wijbrandts CA, Van Baarsen LG, Nader G, Klareskog L, Catrina A et al. The gene expression profile in the synovium as a predictor of the clinical response to infliximab treatment in rheumatoid arthritis. PLoS One 2010; 5: e11310.

81 Klaasen R, Thurlings RM, Wijbrandts CA, van Kuijk AW, Baeten D, Gerlag DM et al. The relationship between synovial lymphocyte aggregates and the clinical response to infliximab in rheumatoid arthritis: a prospective study. Arthritis Rheum 2009; 60: 3217-3224.

82 van Baarsen LG, Wijbrandts CA, Gerlag DM, Rustenburg F, van der Pouw Kraan TC, Dijkmans BA et al. Pharmacogenomics of infliximab treatment using peripheral blood cells of patients with rheumatoid arthritis. Genes Immun 2010; 11: 622-629.

83 Sekiguchi N, Kawauchi S, Furuya T, Inaba N, Matsuda K, Ando S et al. Messenger ribonucleic acid expression profile in peripheral blood cells from RA patients following treatment with an anti-TNF-alpha monoclonal antibody, infliximab. Rheumatology 2008; 47: 780-788.

84 van Baarsen LG, Wijbrandts CA, Rustenburg F, Cantaert T, van der Pouw Kraan TC, Baeten DL et al. Regulation of IFN response gene activity during infliximab treatment in rheumatoid arthritis is associated with clinical response to treatment. Arthritis Res Ther 2010; 12: R11.

85 Tanino M, Matoba R, Nakamura S, Kameda H, Amano K, Okayama $T$ et al. Prediction of efficacy of anti-TNF biologic agent, infliximab, for rheumatoid arthritis patients using a comprehensive transcriptome analysis of white blood cells. Biochem Biophys Res Commun 2009; 387: 261-265.

86 Julia A, Erra A, Palacio C, Tomas C, Sans X, Barcelo P et al. An eight-gene blood expression profile predicts the response to infliximab in rheumatoid arthritis. PLoS One 2009; 4: e7556.

87 Stuhlmuller B, Haupl T, Hernandez MM, Grutzkau A, Kuban RJ, Tandon N et al. CD11c as a transcriptional biomarker to predict response to anti-TNF monotherapy with adalimumab in patients with rheumatoid arthritis. Clin Pharmacol Ther 2010; 87: 311-321.

88 Badot V, Galant C, Nzeusseu Toukap A, Theate I, Maudoux AL, Van den Eynde BJ et al. Gene expression profiling in the synovium identifies a predictive signature of absence of response to adalimumab therapy in rheumatoid arthritis. Arthritis Res Ther 2009; 11: R57.

89 Koczan D, Drynda S, Hecker M, Drynda A, Guthke R, Kekow J et al. Molecular discrimination of responders and nonresponders to anti-TNF alpha therapy in rheumatoid arthritis by etanercept. Arthritis Res Ther 2008; 10: R50.

90 Julia A, Barcelo M, Erra A, Palacio C, Marsal S. Identification of candidate genes for rituximab response in rheumatoid arthritis patients by microarray expression profiling in blood cells. Pharmacogenomics 2009; 10: 1697-1708.

91 Raterman HG, Vosslamber S, De Ridder S, Nurmohamed MT, Lems WF, Boers $\mathrm{M}$ et al. Interferon type I signature may predict non response upon rituximab in rheumatoid arthritis patients. Arthritis Res Ther 2012; 14: R95.

92 Thurlings RM, Boumans M, Tekstra J, van Roon JA, Vos K, van Westing DM et al. Relationship between the type I interferon signature and the response to rituximab in rheumatoid arthritis patients. Arthritis Rheum 2010; 62: 3607-3614.

93 Vosslamber S, Raterman H, van der Pouw Kraan T, Schreurs M, von Blomberg B, Nurmohamed $\mathrm{M}$ et al. Pharmacological induction of interferon type I activity following treatment with rituximab determines clinical response in rheumatoid arthritis. Ann Rheum Dis 2011; 70: 1153-1159.

94 Bansard C, Lequerre T, Derambure C, Vittecoq O, Hiron M, Daragon A et al. Gene profiling predicts rheumatoid arthritis responsiveness to IL-1Ra (anakinra). Rheumatology 2011; 50: 283-292.

95 Nishimoto N, Hashimoto J, Miyasaka N, Yamamoto K, Kawai S, Takeuchi T et al. Study of active controlled monotherapy used for rheumatoid arthritis, an IL- 6 inhibitor (SAMURAI): evidence of clinical and radiographic benefit from an $\mathrm{x}$ ray reader-blinded randomised controlled trial of tocilizumab. Ann Rheum Dis 2007; 66: 1162-1167.

96 Jones G, Sebba A, Gu J, Lowenstein MB, Calvo A, Gomez-Reino JJ et al. Comparison of tocilizumab monotherapy versus methotrexate monotherapy in patients with moderate to severe rheumatoid arthritis: the AMBITION study. Ann Rheum Dis 2010; 69: 88-96.

97 Maini RN, Taylor PC, Szechinski J, Pavelka K, Bröll J, Balint G et al. Double-blind randomized controlled clinical trial of the interleukin- 6 receptor antagonist tocilizumab, in European patients with rheumatoid arthritis who had an incomplete response to methotrexate. Arthritis Rheum 2006; 54: 2817-2829.

98 Mesko B, Poliska S, Szamosi S, Szekanecz Z, Podani J, Varadi C et al. Peripheral blood gene expression and igg glycosylation profiles as markers of tocilizumab treatment in rheumatoid arthritis. J Rheumatol 2012; 39: 916-928.

99 Ioannidis JP, Allison DB, Ball CA, Coulibaly I, Cui X, Culhane AC et al. Repeatability of published microarray gene expression analyses. Nat Genet 2009; 41: 149-155.

100 Cui J, Stahl EA, Saevarsdottir S, Miceli C, Diogo D, Trynka G et al. Genome-wide association study and gene expression analysis identifies CD84 as a predictor of response to etanercept therapy in rheumatoid arthritis. PLoS Genet 2013; 9 e1003394.

101 Toonen EJM, Gilissen C, Franke B, Kievit W, Eijsbouts AM, den Broeder AA et al. Validation study of existing gene expression signatures for anti-TNF treatment in patients with rheumatoid arthritis. PLoS One 2012; 7: e33199.

102 Bienkowska JR, Dalgin GS, Batliwalla F, Allaire N, Roubenoff R, Gregersen PK et al. Convergent Random Forest predictor: methodology for predicting drug 
response from genome-scale data applied to anti-TNF response. Genomics 2009; 94: 423-432.

103 Meugnier E, Coury F, Tebib J, Ferraro-Peyret C, Rome S, Bienvenu J et al. Gene expression profiling in peripheral blood cells of patients with rheumatoid arthritis in response to anti-TNF- $\alpha$ treatments. Physiol Genomics 2011; 43: 365-371.

104 Pheasant M, Mattick JS. Raising the estimate of functional human sequences. Genome Res 2007; 17: 1245-1253.

105 Soifer HS, Rossi JJ, Sætrom P. MicroRNAs in disease and potential therapeutic applications. Mol Ther 2007; 15: 2070-2079.

106 Flynt AS, Lai EC. Biological principles of microRNA-mediated regulation: shared themes amid diversity. Nat Rev Genet 2008; 9: 831-842.

107 Duroux-Richard I, Jorgensen C, Apparailly F. miRNAs and rheumatoid arthritispromising novel biomarkers. Swiss Med Wkly 2011; 141: w13175.

108 Zampetaki A, Kiechl S, Drozdov I, Willeit P, Mayr U, Prokopi M et al. Plasma microRNA profiling reveals loss of endothelial MiR-126 and other microRNAs in type 2 diabetes: novelty and significance. Circ Res 2010; 107: 810-817.

109 Lai CY, Yu SL, Hsieh MH, Chen CH, Chen HY, Wen CC et al. MicroRNA expression aberration as potential peripheral blood biomarkers for schizophrenia. PLoS One 2011; 6: e21635.

110 Li S, Zhu J, Zhang W, Chen Y, Zhang K, Popescu LM et al. Signature microRNA expression profile of essential hypertension and its novel link to human cytomegalovirus infection: clinical perspective. Circulation 2011; 124: 175-184.

111 Chhabra R, Dubey R, Saini N. Cooperative and individualistic functions of the microRNAs in the miR-23a 27a 24-2 cluster and its implication in human diseases. Mol Cancer 2010; 9: 232

112 Alevizos I, Illei GG. MicroRNAs as biomarkers in rheumatic diseases. Nat Rev Rheumatol 2010; 6: 391-398.

$113 \mathrm{Ha}$ TY. MicroRNAs in human diseases: from cancer to cardiovascular disease. Immune Network 2011; 11: 135-154.

114 Meng F, Henson R, Lang M, Wehbe H, Maheshwari S, Mendell JT et al. Involvement of human micro-RNA in growth and response to chemotherapy in human cholangiocarcinoma cell lines. Gastroenterology 2006; 130: 2113-2129.

115 Lu J, Getz G, Miska EA, Alvarez-Saavedra E, Lamb J, Peck D et al. MicroRNA expression profiles classify human cancers. Nature 2005; 435: 834-838.

116 Roldo C, Missiaglia E, Hagan JP, Falconi M, Capelli P, Bersani S et al. MicroRNA expression abnormalities in pancreatic endocrine and acinar tumors are associated with distinctive pathologic features and clinical behavior. J Clin Oncol 2006; 24: 4677-4684.

117 Zhang H, Yang JH, Zheng YS, Zhang P, Chen X, Wu J et al. Genome-wide analysis of small RNA and novel microRNA discovery in human acute lymphoblastic leukemia based on extensive sequencing approach. PLoS One 2009; 4: e6849.

118 Stagakis E, Bertsias G, Verginis P, Nakou M, Hatziapostolou M, Kritikos $\mathrm{H}$ et al. Identification of novel microRNA signatures linked to human lupus disease activity and pathogenesis: miR-21 regulates aberrant $T$ cell responses through regulation of PDCD4 expression. Ann Rheum Dis 2011; 70: 1496-1506.

119 Duroux-Richard I, Presumey J, Courties G, Gay S, Gordeladze J, Jorgensen C et al. MicroRNAs as new player in rheumatoid arthritis. Joint Bone Spine 2011; 78: 17-22.

120 Li J, Wan Y, Guo Q, Zou L, Zhang J, Fang Y et al. Research article: altered microRNA expression profile with miR-146a upregulation in CD4 + T cells from patients with rheumatoid arthritis. Arthritis Res Ther 2010; 12: R81.

121 Murata K, Furu M, Yoshitomi H, Ishikawa M, Shibuya $H$, Hashimoto $M$ et al. Comprehensive microRNA analysis identifies miR-24 and miR-125a-5p as plasma biomarkers for rheumatoid arthritis. PLoS One 2013; 8: e69118.

122 Furer V, Greenberg JD, Attur M, Abramson SB, Pillinger MH. The role of microRNA in rheumatoid arthritis and other autoimmune diseases. Clin Immunol 2010; 136: $1-15$.

123 Stanczyk J, Pedrioli DM, Brentano F, Sanchez-Pernaute O, Kolling C, Gay RE et al. Altered expression of microRNA in synovial fibroblasts and synovial tissue in rheumatoid arthritis. Arthritis Rheum 2008; 58: 1001-1009.

124 de la Rica L, Urquiza JM, Gómez-Cabrero D, Islam AB, López-Bigas N, Tegnér J et al. Identification of novel markers in rheumatoid arthritis through integrated analysis of DNA methylation and microRNA expression. $J$ Autoimmun 2013; 41: 6-16.

125 Nakamachi $Y$, Kawano S, Takenokuchi M, Nishimura K, Sakai Y, Chin T et al. MicroRNA-124a is a key regulator of proliferation and monocyte chemoattractant protein 1 secretion in fibroblast-like synoviocytes from patients with rheumatoid arthritis. Arthritis Rheum 2009; 60: 1294-1304.

126 Kawano S, Nakamachi Y. miR-124a as a key regulator of proliferation and MCP-1 secretion in synoviocytes from patients with rheumatoid arthritis. Ann Rheum Dis 2011; 70(Suppl 1): i88-i91.

127 Pauley KM, Satoh M, Chan AL, Bubb MR, Reeves WH, Chan EKL. Upregulated miR146a expression in peripheral blood mononuclear cells from rheumatoid arthritis patients. Arthritis Res Ther 2008; 10: R101.
128 Alsaleh G, Suffert G, Semaan N, Juncker T, Frenzel L, Gottenberg JE et al. Bruton's tyrosine kinase is involved in miR-346-related regulation of IL-18 release by lipopolysaccharide-activated rheumatoid fibroblast-like synoviocytes. J Immunol 2009; 182: 5088-5097.

129 Niimoto T, Nakasa T, Ishikawa M, Okuhara A, Izumi B, Deie M et al. MicroRNA146 a expresses in interleukin-17 producing $T$ cells in rheumatoid arthritis patients. BMC Musculoskelet Disord 2010; 11: 209.

130 Nakasa T, Miyaki S, Okubo A, Hashimoto M, Nishida K, Ochi M et al. Expression of microRNA-146 in rheumatoid arthritis synovial tissue. Arthritis Rheum 2008; 58: 1284-1292.

131 Stanczyk J, Ospelt C, Karouzakis E, Filer A, Raza K, Kolling C et al. Altered expression of microRNA-203 in rheumatoid arthritis synovial fibroblasts and its role in fibroblast activation. Arthritis Rheum 2011; 63: 373-381.

132 Bauer JW, Bilgic H, Baechler EC. Gene-expression profiling in rheumatic disease: tools and therapeutic potential. Nat Rev Rheumatol 2009; 5: 257-265.

133 Goverdhana S, Puntel M, Xiong W, Zirger JM, Barcia C, Curtin JF et al. Regulatable gene expression systems for gene therapy applications: progress and future challenges. Mol Ther 2005; 12: 189-211.

134 Manasco PK. Ethical and legal aspects of applied genomic technologies: practical solutions. Curr Mol Med 2005; 5: 23-28.

135 Neumaier M. Ethics and quality assessment in genetic testing. J Int Federation Clin Chem Lab Med 2005; 16: 2.

136 Consortium MQC. The MAQC-II Project: a comprehensive study of common practices for the development and validation of microarray-based predictive models. Nat Biotechnol 2010; 28: 827-838.

137 Brazma A, Hingamp P, Quackenbush J, Sherlock G, Spellman P, Stoeckert C et al. Minimum information about a microarray experiment (MIAME) - toward standards for microarray data. Nat Genet 2001; 29: 365-371.

138 Knudsen TB, Daston GP. MIAME guidelines. Reprod Toxicol 2005; 19: 263.

139 van't Veer L, Dai H, van de Vijver M, He Y, Hart A, Mao M et al. Gene expression profiling predicts clinical outcome of breast cancer. Nature 2002; 415: 530-536.

140 Paik S, Shak S, Tang G, Kim C, Baker J, Cronin M et al. A multigene assay to predict recurrence of tamoxifen-treated, node-negative breast cancer. $N$ Engl J Med 2004; 351: 2817-2826.

141 Webber EM, Lin JS, Whitlock EP. Oncotype DX tumor gene expression profiling in stage II colon cancer. Application: prognostic, risk prediction. PLoS Currents 2009; 2: 1341.

142 Ma XJ, Salunga R, Dahiya S, Wang W, Carney E, Durbecq V et al. A five-gene molecular grade index and HOXB13: IL17BR are complementary prognostic factors in early stage breast cancer. Clin Cancer Res 2008; 14: 2601-2608.

143 Sotiriou C, Pusztai L. Gene-expression signatures in breast cancer. N Engl J Med 2009; 360: 790-800.

144 Jerevall PL, Ma XJ, Li H, Salunga R, Kesty NC, Erlander MG et al. Prognostic utility of HOXB13: IL17BR and molecular grade index in early-stage breast cancer patients from the Stockholm trial. Br J Cancer 2011; 104: 1762-1769.

145 Ross JS, Hatzis C, Symmans WF, Pusztai L, Hortobagyi GN. Commercialized multigene predictors of clinical outcome for breast cancer. Oncologist 2008; 13 : 477-493.

146 Ebbert MTW, Bastien RRL, Boucher KM, Martín M, Carrasco E, Caballero R et al. Characterization of uncertainty in the classification of multivariate assays: application to PAM50 centroid-based genomic predictors for breast cancer treatment plans. J Clin Bioinformatics 2011; 1: 1-9.

147 Bastien RRL, Rodríguez-Lescure Á, Ebbert MTW, Prat A, Munárriz B, Rowe L et al. PAM50 breast cancer subtyping by RT-qPCR and concordance with standard clinical molecular markers. BMC Med Genomics 2012; 5: 44

148 de Snoo F, Bender R, Glas A, Rutgers E. Gene expression profiling: decoding breast cancer. Surg Oncol 2009; 18: 366.

149 Hornberger J, Alvarado MD, Rebecca C, Gutierrez HR, Tiffany MY, Gradishar WJ. Clinical validity/utility, change in practice patterns, and economic implications of risk stratifiers to predict outcomes for early-stage breast cancer: a systematic review. J Natl Cancer Inst 2012; 104: 1068-1079.

150 Roedder S, Vitalone M, Khatri P, Sarwal MM. Biomarkers in solid organ transplantation: establishing personalized transplantation medicine. Genome Med 2011; 3: 37.

151 Rosenberg S, Elashoff MR, Lieu HD, Brown BO, Kraus WE, Schwartz RS et al. Whole blood gene expression testing for coronary artery disease in nondiabetic patients: major adverse cardiovascular events and interventions in the PREDICT trial. J Cardiovasc Transl Res 2012; 5: 1-9.

152 Voros S, Elashoff MR, Sehnert AJ, Lieu HD, Wingrove JA, Daniels SE et al. $A$ validated, peripheral blood gene expression pattern correlates with coronary arterial plaque burden by quantitative coronary angiography and coronary artery calcium scoring. J Am Coll Cardiol 2011; 57: E1157-E1157.

153 Booij BB, Lindahl T, Wetterberg P, Skaane NV, Sæbø S, Feten G et al. A gene expression pattern in blood for the early detection of Alzheimer's disease. J Alzheimer's Dis 2011; 23: 109-119. 
154 Rye PD, Booij BB, Grave G, Lindahl T, Kristiansen L, Andersen HM et al. A novel blood test for the early detection of Alzheimer's disease. J Alzheimer's Dis 2011; 23: $121-129$.

155 Costanzo MR, Dipchand A, Starling R, Anderson A, Chan M, Desai S et al. The International Society of Heart and Lung Transplantation Guidelines for the care of heart transplant recipients. J Heart Lung Transplant 2010; 29: 914-956.

156 van der Pouw Kraan T, Van Gaalen F, Huizinga T, Pieterman E, Breedveld F, Verweij $C$. Discovery of distinctive gene expression profiles in rheumatoid synovium using CDNA microarray technology: evidence for the existence of multiple pathways of tissue destruction and repair. Genes Immun 2003; 4: 187-196.

157 Lindberg J, af Klint E, Ulfgren AK, Stark A, Andersson T, Nilsson P et al. Variability in synovial inflammation in rheumatoid arthritis investigated by microarray technology. Arthritis Res Ther 2006; 8: R47.

158 Timmer TCG, Baltus B, Vondenhoff M, Huizinga TWJ, Tak PP, Verweij CL et al. Inflammation and ectopic lymphoid structures in rheumatoid arthritis synovial tissues dissected by genomics technology: Identification of the interleukin-7 signaling pathway in tissues with lymphoid neogenesis. Arthritis Rheum 2007; 56: 2492-2502.

159 Huber R, Hummert C, Gausmann U, Pohlers D, Koczan D, Guthke R et al. Identification of intra-group, inter-individual, and gene-specific variances in mRNA expression profiles in the rheumatoid arthritis synovial membrane. Arthritis Res Ther 2008; 10: R98.

160 Ungethuem U, Haeupl T, Witt H, Koczan D, Krenn V, Huber $\mathrm{H}$ et al. Molecular signatures and new candidates to target the pathogenesis of rheumatoid arthritis. Physiol Genomics 2010; 42A: 267-282.

161 Watanabe N, Ando K, Yoshida S, Inuzuka S, Kobayashi M, Matsui N et al. Gene expression profile analysis of rheumatoid synovial fibroblast cultures revealing the overexpression of genes responsible for tumor-like growth of rheumatoid synovium. Biochem Biophys Res Commun 2002; 294: 1121-1129.

162 Kasperkovitz PV, Timmer TCG, Smeets TJ, Verbeet NL, Tak PP, Baltus B et al. Fibroblast-like synoviocytes derived from patients with rheumatoid arthritis show the imprint of synovial tissue heterogeneity: Evidence of a link between an increased myofibroblast-like phenotype and high-inflammation synovitis. Arthritis Rheum 2005; 52: 430-441.

163 Van der Pouw Kraan T, Wijbrandts C, van Baarsen L, Voskuyl A, Rustenburg F, Baggen $\mathrm{J}$ et al. Rheumatoid arthritis subtypes identified by genomic profiling of peripheral blood cells: assignment of a type I interferon signature in a subpopulation of patients. Ann Rheum Dis 2007; 66: 1008-1014.

164 van der Pouw Kraan T, van Baarsen L, Wijbrandts C, Voskuyl A, Rustenburg F, Baggen J et al. Expression of a pathogen-response program in peripheral blood cells defines a subgroup of rheumatoid arthritis patients. Genes Immun 2007; 9: 16-22

165 Bovin LF, Rieneck K, Workman C, Nielsen H, Sørensen SF, Skjødt H et al. Blood cell gene expression profiling in rheumatoid arthritis: discriminative genes and effect of rheumatoid factor. Immunol Lett 2004; 93: 217-226.

166 Olsen N, Sokka T, Seehorn C, Kraft B, Maas K, Moore J et al. A gene expression signature for recent onset rheumatoid arthritis in peripheral blood mononuclear cells. Ann Rheum Dis 2004; 63: 1387-1392.

167 Batliwalla F, Baechler E, Xiao X, Li W, Balasubramanian S, Khalili H et al. Peripheral blood gene expression profiling in rheumatoid arthritis. Genes Immun 2005; 6: 388-397.

168 Teixeira VH, Olaso R, Martin-Magniette M-L, Lasbleiz S, Jacq L, Oliveira CR et al. Transcriptome analysis describing new immunity and defense genes in peripheral blood mononuclear cells of rheumatoid arthritis patients. PLoS One 2009; 4: e6803.

169 Junta CM, Sandrin-Garcia P, Fachin-Saltoratto AL, Mello SS, Oliveira RDR, Rassi $\mathrm{DM}$ et al. Differential gene expression of peripheral blood mononuclear cells from rheumatoid arthritis patients may discriminate immunogenetic, pathogenic and treatment features. Immunology 2009; 127: 365-372.

170 Grcevic D, Jajic Z, Kovacic N, Lukic I, Velagic V, Grubisic F et al. Peripheral blood expression profiles of bone morphogenetic proteins, tumor necrosis factorsuperfamily molecules, and transcription factor Runx 2 could be used as markers of the form of arthritis, disease activity, and therapeutic responsiveness. J Rheumatol 2010; 37: 246-256.

171 Liu Z, Sokka T, Maas K, Olsen NJ, Aune TM. Prediction of disease severity in patients with early rheumatoid arthritis by gene expression profiling. Hum Genomics Proteomics 2009; 2009: 10; doi:10.4061/2009/484351.

172 Szodoray P, Alex P, Frank M, Turner M, Turner S, Knowlton N et al. A genome scale assessment of peripheral blood B-cell molecular homeostasis in patients with rheumatoid arthritis. Rheumatology 2006; 45: 1466-1476.

173 Haas CS, Creighton CJ, Pi X, Maine I, Koch AE, Haines GK et al. Identification of genes modulated in rheumatoid arthritis using complementary DNA microarray analysis of lymphoblastoid B cell lines from disease-discordant monozygotic twins. Arthritis Rheum 2006; 54: 2047-2060.

174 Lee HM, Sugino H, Aoki C, Shimaoka Y, Suzuki R, Ochi K et al. Abnormal networks of immune response-related molecules in bone marrow cells from patients with rheumatoid arthritis as revealed by DNA microarray analysis. Arthritis Res Ther 2011; 13: R89.

175 Pratt A, Brown P, Cockell S, Wilson G, Isaacs J. A3.2 A CD4 + T-cell gene expression signature predicts drug survival on methotrexate monotherapy in early rheumatoid arthritis. Ann Rheum Dis 2013; 72(Suppl 1): A13-A14.

176 Mans K, Tandon N, Sohnrey C, Bolle S, Grützkau A, Burmester G et al. A7.17 microarray gene expression profiling of rheumatoid arthritis patients for prediction of response to methotrexate treatment. Ann Rheum Dis 2013 72(Suppl 1): A54.

177 Soldano S, Villaggio B, Gallo F, Montagna P, Brizzolara R, Cutolo M. Modulation of gene expression by leflunomide and prednisone during treatment of early rheumatoid arthritis. Ann Rheum Dis 2010; 69(Suppl 2): A31-A32.

178 Szekanecz Z, Meskó B, Poliska S, Váncsa A, Palatka K, Holló Z et al. A7.20 response to infliximab therapy can be predicted using distinct, non-overlapping gene panels of peripheral blood gene expression in rheumatoid arthritis and crohn's disease. Ann Rheum Dis 2013; 72(Suppl 1): A55.

179 Gutierrez-Roelens I, Galant C, Théate I, Lories R, Durez P, Nzeusseu-Toukap A et al. Rituximab treatment induces the expression of genes involved in healing processes in the rheumatoid arthritis synovium. Arthritis Rheum 2011; 63 1246-1254.

180 Hogan VE, Holweg CTJ, Choy DF, Kummerfeld SK, Hackney JA, Teng YKO et al. Pretreatment synovial transcriptional profile is associated with early and late clinical response in rheumatoid arthritis patients treated with rituximab. Ann Rheum Dis 2012.

181 Oliveira RDR, Fontana V, Junta CM, Marques MMC, Macedo C, Rassi DM et al. Differential gene expression profiles may differentiate responder and nonresponder patients with rheumatoid arthritis for methotrexate (MTX) monotherapy and MTX plus tumor necrosis factor inhibitor combined therapy. J Rheumatol 2012; 39: 1524-1532.

182 Parker A, Izmailova ES, Narang J, Badola S, Le T, Roubenoff R et al. Peripheral blood expression of nuclear factor-kappab-regulated genes is associated with rheumatoid arthritis disease activity and responds differentially to anti-tumor necrosis factor-alpha versus methotrexate. J Rheumatol 2007; 34: 1817-1822.

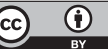

This work is licensed under a Creative Commons Attribution 3.0 Unported License. To view a copy of this license, visit http:// creativecommons.org/licenses/by/3.0/ 